\title{
PERAN PERATURAN BANGUNAN KHUSUS DALAM MENGURANGI PERUBAHAN KUALITAS KAWASAN CAGAR BUDAYA KRATON YOGYAKARTA
}

\author{
Rully \\ Program Studi Arsitektur Fakultas Teknik Universitas Tunas Pembangunan \\ rullystmt@gmail.com
}

\begin{abstract}
Abstrak
Pada umumnya kawasan yang berpotensi di Indonesia belum dikelola secara baik, sebagian peraturan masih bersifat peraturan secara umum, tetapi belum berfungsi sebagai alat pengendali operasional di lapangan, sehingga diperlukan peraturan yang mampu menjangkau ke arah pengendalian arsitektur bangunan secara tiga dimensional. Penyusunan peraturan bangunan khusus merupakan rancangan pengendalian bangunan kawasan yang diperlukan setelah adanya rencana tata ruang kota, untuk mewujudkan tertib bangunan agar sesuai dengan karakteristik bangunan setempat, pengaturan keselamatan bangunan yang bertujuan agar setiap bangunan dapat memberikan kenyamanan bagi penghuninya. Pengembangan obyek pariwisata diperlukan langkah yang terpadu untuk menjaga kelestarian dan mutu lingkungan hidupnya, kota Yogyakarta dengan beraneka ragam arsitekturnya dan kawasan wisata yang banyak berperan dalam menyerap wisatawan, akan berdampak pada peningkatan kualitas bangunan dimasa datang dan aktifitas pariwisatanya. Dari masalah tersebut kawasan Cagar Budaya Kraton Yogyakarta sudah memerlukan adanya suatu peraturan bangunan khusus sebagai alat pengendali pembangunan fisik.
\end{abstract}

Kata Kunci : Peraturan Bangunan Khusus, Perubahan Kualitas Kawasan

\begin{abstract}
In general, areas that have the potential in Indonesia have not been properly managed, some regulations are still in general regulations, but have not functioned as operational control tools in the field, so regulations are needed that can reach threedimensional building architecture control. The preparation of special building regulations is a design of building control of the area needed after the city spatial plan, to realize orderly buildings to fit the characteristics of local buildings, building safety arrangements that aim for each building to provide comfort for its residents. Tourism object development requires integrated steps to preserve and preserve the quality of its environment, the city of Yogyakarta with its diverse architecture and tourist areas which have many roles in absorbing tourists, will have an impact on improving the quality of buildings in the future and tourism activities. From this problem, the Yogyakarta Palace Cultural Heritage area already requires the existence of a special building regulation as a means of controlling physical development.
\end{abstract}

Keywords: Special Building Regulations, Changes in Regional Quality

\section{Pendahuluan}

Sebagian besar kawasan berpotensi di Indonesia belum dikelola secara baik, sebagian peraturan masih bersifat umum, belum berfungsi sebagai pengendali pada operasional di lapangan.

Sering terlupakan adalah produk peraturan belum mencakup aturan 
terhadap bangunan khusus pada suatu kawasan. Sehingga untuk mewujudkan suatu pengendalian bangunan yang telah direncanakan perlu peraturan bangunan.

Penyusunan peraturan bangunan khusus merupakan rancangan pengendalian bangunan kawasan yang diperlukan setelah adanya rencana tata ruang kota. Penyusunan peraturan bangunan khusus dimaksudkan untuk mewujudkan tertib bangunan serta pengaturan keselamatan bangunan memberikan keamanan dan kenyamanan bagi penghuninya, sehingga sesuai karakteristik bangunan setempat. Kota Yogyakarta sebagai kota pendidikan dan pariwisata memiliki beraneka ragam arsitektur, hal ini akan berpengaruh pada peningkatan kualitas bangunan di masa yang akan datang dan akan memberikan dampak pada kegiatan kepariwisataan di kota tersebut. Dari masalah tersebut Kawasan Kraton Yogyakarta memerlukan adanya suatu peraturan bangunan khusus sebagai pengendali pembangunan fisik, sehingga diharapkan mampu menindak lanjuti Rencana Tata Ruang dan Kawasan yang sudah ada.

1.1. Lingkup Kegiatan Penelitian
Lingkup kegiatan dalam penelitian
ini mencakup transformasi fungsi kawasan, karakteristik alam, arsitektur, sosial, budaya dan arahan bagi rencana tata bangunan, lingkungan, serta kebijaksanaan pemerintah kota Yogyakarta dalam setiap upaya pembangunan kota, meliputi:

a. Penataan Bangunan

Mengatur penerapan persyaratan rencana tata bangunan dan lingkungan. b. Penyelenggaraan Pembangunan

Meliputi persyaratan perancangan, pelaksanaan, penggunaan, mekanisme penghapusan bangunan dan syaratnya

c. Persyaratan Keselamatan dan Kenyamanan Bangunan

Meliputi ketentuan persyaratan yang harus dipenuhi oleh bangunan agar handal terhadap beban sendiri dan bahaya yang disebabkan alam atau manusia dan yang harus dipenuhi bangunan agar nyaman dan sehat.

d. Persyaratan Perijinan Bangunan

Meliputi: Persyaratan dan prosedur pengurusan ijin mendirikan bangunan (IMB), ijin pemanfaatan bangunan (IPB), dan ijin penghapusan bangunan (IHB) di Kawasan Kraton Yogyakarta.

e. Pengawasan Mendirikan Bangunan Mengatur mekanisme pelaksanaan pendirian bangunan di Kawasan Cagar Budaya Kraton Yogyakarta oleh aparat Pemerintah setempat.

f. Pembinaan

Meliputi : Pemantauan terhadap bangunan yang sudah berdiri, pengaturan peran swasta dan pihak terkait serta masyarakat dalam pembinaan kepada pelaku pembangunan untuk mewujudkan dan memelihara Kawasan Cagar Budaya Kraton Yogyakarta

\subsection{Lingkup Wilayah Studi}

Wilayah kegiatan penelitian ini meliputi keseluruhan Kawasan Cagar Budaya Kraton Yogyakarta Yogyakarta. Letak kawasan studi dalam konstelasi Kota Yogyakarta dapat dilihat pada peta berikut. 


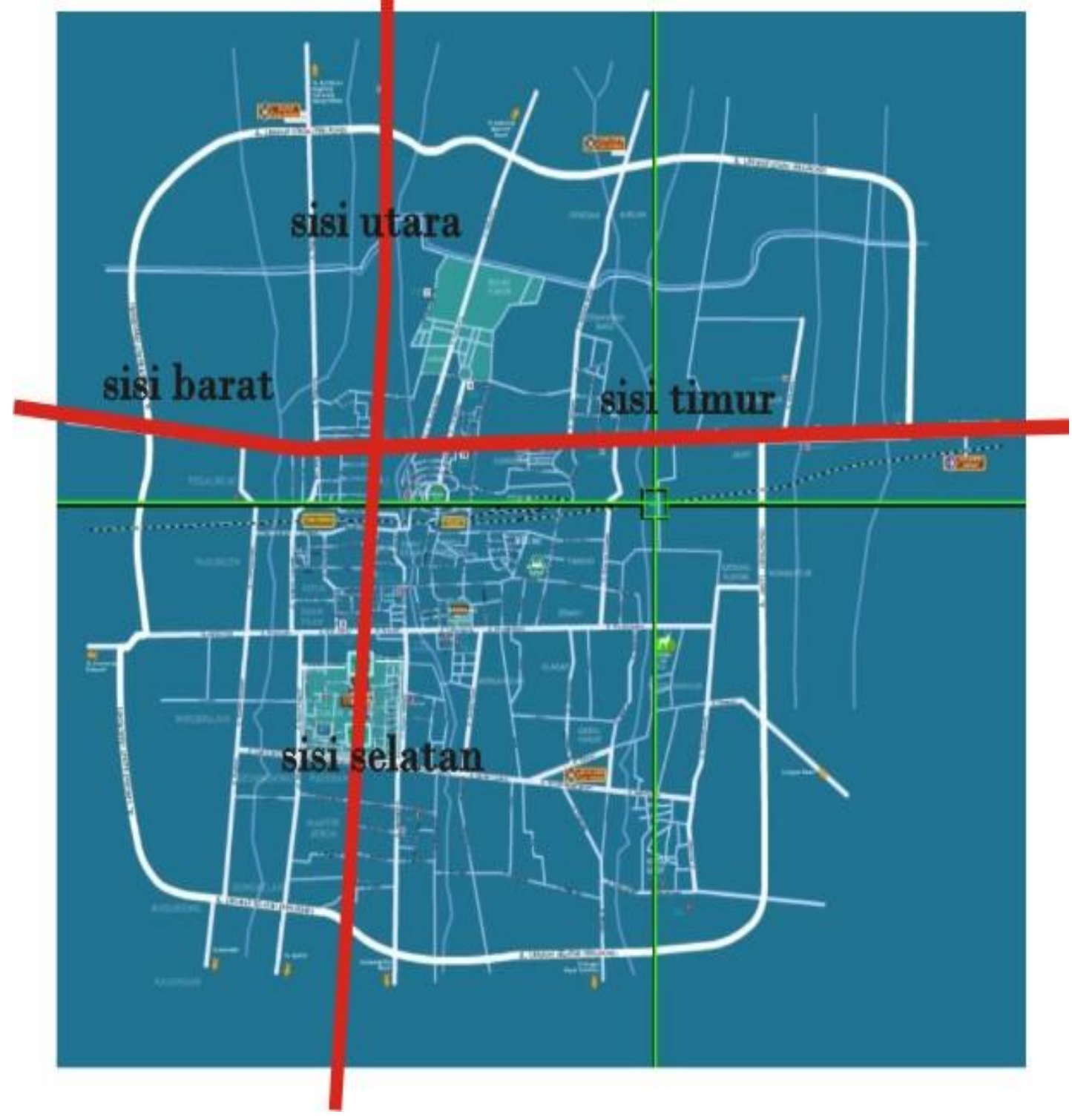

Peta 1.2

Posisi Kawasan Cagar Budaya Kraton Yogyakarta Terhadap Kawasan-kawasan Pengembangan Wilayah di Kota Yogyakarta

\section{Landasan Teori}

Kawasan Kraton Yogyakarta merupakan kawasan yang harus dilestarikan, hal ini dipertegas dengan Undang-undang Republik Indonesia nomor 5 Tahun 1992 tentang benda cagar budaya.

Disebutkan dalam undangundang tersebut bahwa benda cagar budaya penting untuk dilestarikan agar terpeliharanya jati diri setempat, dalam Undang-undang tersebut benda cagar budaya didefinisikan sebagai segala benda baik buatan maupun alam, baik bergerak atau tidak bergerak, baik utuh maupun partial yang berumur lebih dari 50 tahun atau mempunyai kekhasan tertentu atau bergaya lama (lebih dari 50 tahun), dan yang mempunyai arti penting dalam hal kesejarahan, ilmu pengetahuan dan kebudayaan. Terkait dengan benda cagar budaya adalah Situs, yakni lokasi atau yang diduga sebagai lokasi dari benda cagar budaya plus area sekitar tertentu yang menjadi lingkungan pengaman. Benda cagar 
budaya dan Situs, perlu dilestarikan dan dimanfaatkan untuk keperluan tertentu sejauh tidak bertentangan dengan maksud pelestariannya.

Dalam pelaksanaannya UndangUndang Nomor 5 tahun 1992 tersebut diikuti oleh Peraturan Pemerintah yang mengatur hal-hal yang terkait dengan upaya pelestarian benda cagar budaya. Peraturan Pemerintah Nomor 10 tahun 1993 tentang Pelaksanaan UndangUndang Nomor 5 tahun 1992 tentang benda cagar budaya ini memberikan aturan lebih lanjut tentang penguasaan, pemilihan, pendaftaran, pengalihan, penemuan, pencarian, perlindungan, pemeliharaan, pemanfaatan, pembinaan dan pengawasan.

Meskipun sudah merupakan penjabaran yang memberikan kejelasan atas Undang-Undang Nomor 5 tahun 1992 serta menjadi pedoman pelaksanaannya, untuk hal-hal yang sangat teknis Peraturan Pemerintah Nomor 10 tahun 1993 ini disertai pula dengan serangkaian Surat keputusan menteri.

Dari beberapa studi terdahulu yang diprediksikan akan memberi pengaruh pada kegiatan penelitian ini diperoleh gambaran bahwa selain kebijakan umum, program pembangunan rencana tata ruang, hingga peraturan yang berkenaan dengan pembangunan fisik dan prasarana lingkungan, terdapat juga sejumlah hasil studi yang telah dilakukan sebelumnya, diantaranya adalah:

a. Penelitian Bangunan di Kawasan Kraton. Studi ini dilaksanakan oleh Fakultas Teknik Universitas Gadjahmada Yogyakarta pada tahun 1994/1995. Studi ini menelaah keadaan bangunan yang ada serta memberikan gambaran perlunya dilakukan pengaturan pembangunan lebih lanjut.

b. Kajian Identitas Bentuk Bangunan Daerah Istimewa Yogyakarta (1997/ 1998). Studi ini mencoba menelusuri citra lokal yang dapat membentuk jati diri Yogyakarta melalui bentuk bangunan yang ada di selunuh wilayah Daerah Istimewa Yogyakarta.

c. Rancangan Peraturan Tentang Identitas Bentuk Bangunan Daerah Istimewa Yogyakarta (1998). Studi yang baru saja dilaksanakan ini mencoba memberikan rumusan atas bentuk bangunan yang berwawasan identitas Daerah Istimewa Yogyakarta dan mencari peluang pengaturannya agar jati diri ini dapat terus terpelihara dan berkembang lagi.

\section{Pembahasan}

Hasil dan pembahasan yang diperoleh dari kegiatan penelitian ini mencakup kebijakan dan berbagai program pembangunan daerah, berbagai peraturan dan perundangan yang terkait dengan upaya pelestarian kawasan dan benda cagar budaya, rencana tata ruang dan prasarana, pelaksanaan dan pengendalian pembangunan, , gambaran keadaan Kawasan Cagar Budaya Kraton Yogyakarta, dan arahan bagi peraturan bangunan khusus, yang merupakan hasil akhir dari pembahasan penelitian ini.

\subsection{Kebijakan Program Pembangunan Daerah}

Diukur dari materi yang diharapkan dari kegiatan penelitian yang mengarah pada penyusunan peraturan bangunan, terdapat kebijakan daerah dan program pembangunan yang sifat dan cakupannya masih sangat umum. Keduanya adalah Pola Dasar Pembangunan Daerah dan Rencana Pembangunan Lima Tahun Daerah. Disamping lebar cakupan substansi, secara kewenangan cakupan yang paling mendekati lingkup pekerjaan adalah pada level Kota Yogyakarta. Karena sifatnya yang 
masih sangat makro tersebut, dapat disimpulkan kecil sekali relevansi langsung pada studi ini. Untuk itu diperlukan acuan lain yang berupa rencana pengembangan yang lebih khusus. Lepas dari itu, satu hal yang bisa dicatat dari arahan pembangunan daerah bagi kota Yogyakarta adalah tekad untuk tetap mempertahankan ciri asli yang menjadi asal terbentuknya kota. Dalam hal ini Kraton beserta kawasannya adalah inti pertumbuhan kota. Segala sesuatu didalam wilayah ini masih tetap relevan untuk selalu dipertahankan dan dilestarikan. Bukan hanya bagi kepentingan masa kini, bahkan untuk masa mendatang masih banyak manfaat yang bisa ditarik dari keberadaan Kawasan Cagar Budaya Kraton Yogyakarta untuk pengembangan pariwisata.

Dari rencana tata ruang yang telah berhasil disusun, rumusan kebijaksanaan dan program pembangunan dirumuskan dengan didasarkan pada kondisi kesejarahan yang sesuai dengan konsep struktur keruangan Kraton Kasultanan Yogyakarta. Kondisi ini diharapkan dapat menampilkan kembali model perwilayahan dengan pola konsentrik dari suatu Kuthanegara, yakni keberadaan inti atau pusat negarigung, mancanegara, dan pesisiran.

Sejalan dengan model perwilayahan tersebut, penataan yang dirumuskan untuk Kawasan Cagar Budaya Kraton Yogyakarta, tersusun berikut :

a. Inti Kawasan: terdiri atas AlunAlun Lor, Alun-Alun Kidul, dan Kraton.

Ditetapkan sebagai daerah yang diharapkan dapat berkembang sebagai daerah budaya, dengan mempertahankan keaslian cagar budaya yang ada melalui upaya preservasi.
b.Daerah Penunjang-I: berada di sisi luar timur dan barat inti kawasan.

Sisi luar sebelah barat meliputi daerah di luar inti kawasan sampai dengan Jl. Kauman, Jl. Ngasem, Jl. Polowijan, Jl. Nogosari, Jl. Nagan Lor, dan Jl. Patehan Lor. Sedangkan sisi luar sebelah timur meliputi daerah di luar inti kawasan sampai dengan Jl. Wijilan, Jl. Amangkurat, dan Jl. Langenarjan Kidul. Ditetapkan dengan mengatur facade bangunannya berorientasi pada bangunan kraton, karena kedudukannya yang secara langsung dipengaruhi oleh inti kawasan. Pada beberapa obyek yang berupa dalem pangeran dan rumah abdi dalem ditetapkan dalam bentuk penanganan preservasi adaptif. Kegiatan lalulintas dan transportasi dibatasai dengan ketat.

c.Daerah Penunjang-II: berada di sisi luar dari daerah penunjang-I sampai dengan tembok beteng.

Ditetapkan peruntukannya sebagai pemukiman dan fasilitas pelayanan lingkungan setempat. Direncanakan melalui pengaturan: kepadatan penduduk, pemanfaatan ruang, arus pergerakan, fisik bangunan berikut pengembangannya untuk bangunan magersari dan ngindung, peningkatan kualitas lingkungan, dan pembatasan bangunan yang langsung berada di sisi tembok beteng.

d.Daerah Penunjang-III: daerah jagang dan jalan besar yang mengelilingi hingga satu persil di tepi jalan.

Ditetapkan sebagai daerah transformasi agar mampu membatasi dan menjembatani Kawasan Cagar Budaya Kraton Yogyakarta dengan kawasan sekitarnya.

Dalam rangka pelaksanaan dan pengendalian pembangunan di wilayah 
Kota Yogyakarta, selama ini telah diterapkan berbagai peraturan. Beberapa peraturan lama telah digantikan dengan yang lebih besar lagi, disesuaikan dengan perkembangan kebutuhan masyarakat. Berikut ini disajikan perangkat hukum yang pernah diberlakukan tersebut:

a.Peraturan Daerah Istimewa

Yogyakarta Nomor 24 Tahun 1956

tentang Petunjuk Bagi Penata

Sempadan Jalan.

b.Peraturan Daerah Istimewa

Yogyakarta Nomor 1 Tahun 1960

tentang Peraturan Sempadan,

Pembuatan dan Pembongkaran

Bangunan.

c.Peraturan Daerah Kotapraja Daerah Tingkat II Yogyakarta Nomor 2 Tahun 1960 tentang Tarip Biaya Sempadan, peraturan ini memuat cara perhitungan dan penentuan tarip biaya sempadan bangunan.

d.Peraturan Daerah Kotapraja Daerah Tingkat II Yogyakarta Nomor 4 Tahun 1976, tentang Tarif Bea Sempadan, peraturan ini memuat cara penetapan bea sempadan yang didasarkan pada nilai bangunan yang diperhitungkan atas dasar koefisien golongan bangunan dan indeks harga bangunan.

e.Peraturan Daerah Istimewa Yogyakarta Nomor 2 Tahun 1960 tentang Pemeliharaan Daerah Istimewa Yogyakarta, peraturan ini memuat kewajiban warga masyarakat dalam hal pemeliharaan Kebaikan, Kerapian, Kebersihan, Kesehatan dan Ketenteraman Lingkungan serta Larangan mengunakan jalan atau tempat umum untuk jenis kegiatan dan pekerjaan.

f. Peraturan Daerah Kotamadya Daerah Tingkat II Nomor 7 Tahun 1986 tentang Rencana Induk Kota Yogyakarta 1985-2005.
g.Peraturan Daerah Kotamadya Daerah Tingkat II Nomor 4 Tahun 1988 tentang Bangunan.

h.Peraturan Daerah Kotamadya Daerah Tingkat II Nomor 6 Tahun 1994 tentang Rencana Umum Tata Ruang Kota Yogyakarta 1994-2004.

i. Peraturan Daerah Kotamadya Daerah Tingkat II Nomor 1 Tahun 1992 tentang Yogyakarta Berhati Nyaman.

j. Peraturan Daerah Kotapraja Daerah Tingkat II Yogyakarta Nomor 14 Tahun 1958 tentang Pembuangan Air.

k.Surat Penetapan Walikotamadya Daerah Tingkat II Yogyakarta Nomor 69/KA/1976 tentang Pelaksanaan Peraturan Restribusi Pemeliharaan Aseinering Daerah Kota Yogyakarta.

1. Peraturan Daerah Kotamadya Daerah Tingkat II Yogyakarta Nomor 10 Tahun 1977 tentang Buangan Sampah.

m.Penetapan Walikotamadya Kepala Daerah Tingkat II Yogyakarta Nomor 6 Tahun 1978 tentang Pemungutan Restribusi Sampah, Pengambilan dan Pembuangan Sampah.

3.2. Gambaran Keadaan Kawasan Cagar Budaya Kraton Yogyakarta

Gambaran keadaan Kawasan Cagar Budaya Kraton Yogyakarta, sebagai wilayah penelitian tentang Peran Peraturan Bangunan Khusus dalam Meminimalisir Degradasi Kualitas Kawasan Cagar Budaya Kraton Yogyakarta, sebagai berikut:

a. Administrasi Wilayah. $\begin{array}{lr}\text { Adapun } & \text { batas-batas } \\ \text { administrasi } & \text { wilayah }\end{array}$ Kecamatan Kraton adalah : Sebelah Utara : Wilayah Kecamatan Ngampilan dan Gondomanan. 
Sebelah Timur : Wilayah

Kecamatan Gondomanan dan

Mergangsan.

Sebelah Selatan : Wilayah

Kecamatan Mantrijeron .
Sebelah Barat : Wilayah

Kecamatan Mantrijeron dan

Ngampilan.

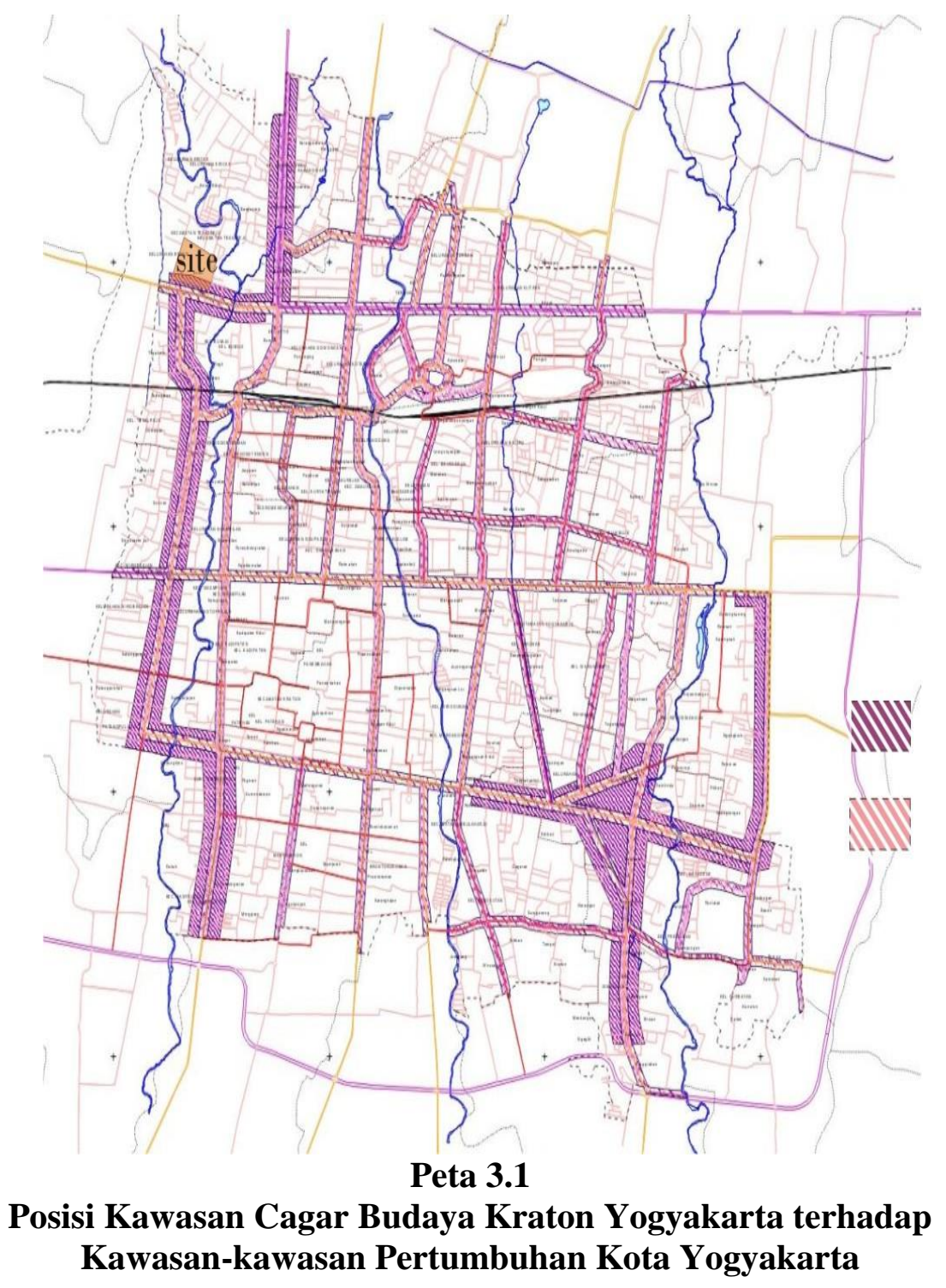

Wilayah Kecamatan Kraton secara administratif dibagi dalam tiga kelurahan yaitu : 1) Kel.Patehan; 2) Kel.Panembahan; 3) Kel.Kadipaten. Luas wilayah keraton adalah seluas $1,40 \mathrm{Km}^{2}$ dengan ketinggian $\pm 100 \mathrm{~m}$ di atas permukaan laut, dengan tingkat kemiringan yang relatif sangat kecil. Curah hujan berkisar antara $2.000 \mathrm{~mm}$

sampai dengan $3.000 \mathrm{~mm}$ per tahun, dengan jumlah hari hujan adalah 180 hari pertahun, yaitu mulai bulan Oktober sampai dengan bulan Maret, 
dengan iklim tropis yang suhu minimum $26^{\circ} \mathrm{C}$ dan maksimun $36^{\circ} \mathrm{C}$.

Gambaran secara lebih rinci mengenai luas wilayah dan penggunaan lahan di Kecamatan Kraton pada Tahun 2009 dapat dilihat dalam tabel berikut ini.

Tabel 3.1

Luas Wilayah Menurut Jenis Penggunaan Lahan Di Kecamatan Kraton Tahun 2009 (Ha)

\begin{tabular}{|l|c|c|c|c|}
\hline Kelurahan & Jalan & $\begin{array}{c}\text { Bangunan/ } \\
\text { Pekarangan }\end{array}$ & Lain-Lain & Jumlah \\
\hline Patehan & 4,85 & 35,02 & 0,30 & 40,00 \\
\hline Panembahan & 9,58 & 52,42 & 4,00 & 66,00 \\
\hline Kadipaten & 6,19 & 23,26 & 4,55 & 34,00 \\
\hline Jumlah & $\mathbf{2 0 , 6 2}$ & $\mathbf{1 1 0 , 7 0}$ & $\mathbf{8 , 6 8}$ & $\mathbf{1 4 0 , 0 0}$ \\
\hline
\end{tabular}

Sumber: Kecamatan Kraton Dalam Angka, 2010

Dari segi demografis, wilayah Kecamatan Kraton merupakan salah satu wilayah yang telah memiliki kepadatan penduduk yang relatif padat. Sebagaimana pada umumnya wilayah perkotaan, wilayah Kecamatan Kraton memiliki tingkat perkembangan penduduk yang selalu bertambah dari tahun ke tahun. Adapun perkembangan penduduk di wilayah Kecamatan Kraton, banyaknya kepala keluarga serta perkembangan tingkat kepadatannya selama tahun 1996-2009 dapat dilihat dalam tabel berikut ini :

Tabel 3.2

Jumlah Penduduk, Kepala Keluarga Dan Tingkat Kepadatan Penduduk Di Kecamatan Kraton Tahun 2008-2009

\begin{tabular}{|c|c|c|c||}
\hline Tahun & $\begin{array}{c}\text { Jumlah } \\
\text { Penduduk } \\
\text { (Jiwa) }\end{array}$ & $\begin{array}{c}\text { Jumlah Kepala } \\
\text { Keluarga }\end{array}$ & $\begin{array}{c}\text { Tingkat Kepadatan } \\
\text { (Jiwa/Km }{ }^{\text {) }} \text { ) }\end{array}$ \\
\hline 1996 & 30.642 & 7.193 & 21.887 \\
\hline 2009 & 30.777 & 7193 & 21.984 \\
\hline
\end{tabular}

Sumber : Kecamatan Kraton Dalam Angka, 2010

\section{b. Rencana Pengendalian Pem- bangunan.}

Dengan adanya berbagai kebijakan dan program daerah serta rencana pembangunan kota yang juga berlaku di kawasan studi dan beberapa hasil studi, rencana-rencana, maupun pedoman pembangunan yang khusus diberlakukan bagi kawasan ini. Adapun dua diantaranya yang mempunyai relevansi yang sangat erat dan yang masih cukup baru untuk diacu dalam penelitian Peraturan Bangunan Khusus (PBK) dalam mengurangi perubahan kualitas Kawasan Cagar Budaya Kraton Yogyakarta ini adalah studi "Rencana Tata Ruang Dan 
Indikasi Program Kawasan Kraton Yogyakarta" serta "Rencana Tata Bangunan Dan Lingkungan Kawasan Kraton Yogyakarta".

1) Rencana Tata Ruang dan Indikasi Program Kawasan Kraton $\underline{\text { Yogyakarta }}$

Rencana tata ruang ini disusun pada tahun 1988 oleh pemerintah daerah setempat. Kebijaksanaan dan program pembangunan yang dirumuskannya didasarkan pada kondisi kesejarahan yang sesuai dengan konsep struktur keruangan kraton lama. Hal ini dilakukan dengan menampilkan kembali model perwilayahan pola konsentrik dari suatu Kuthanegara, yakni adanya inti atau pusat negarigung, mancanegara dan pesisiran.

Untuk Kawasan Kraton Yogyakarta sendiri, penataannya ditetapkan pembagiannya atas inti kawasan dan daerah-daerah penunjang. Inti kawasan meliputi alun-alun lor dan kidul serta kompleks kraton itu sendiri. Daerah ini dikembangkan sebagai daerah budaya yang dipreservasi/ dipertahankan keasliannya. Upaya pembangunan baru harus dikaji tingkat keperluannya.

Daerah penunjang I berada disisi luar barat dan timur inti kawasan. Daerah yang langsung dipengaruhi oleh inti kawasan ini ungkapan fisiknya diorientasikan juga pada bangunan kraton. Terhadap bangunan-bangunan penting dilakukan preservasi adaptif. Sedangkan lalu lintas umum dibatasi dengan ketat. Lapisan berikutnya adalah daerah penunjang II yang berada disisi luar dari daerah penunjang I hingga ke tembok beteng. Peruntukannya adalah sebagai permukiman dan fasilitas pelayanan lingkungan setempat. Direncanakan dilakukan pengaturan terhadap kepadatan penduduk, pemanfaatan ruang, arus pergerakan, fisik bangunan (magersari dan ngindung), pembatasan bangunan yang menempel tembok beteng dan peningkatan kualitas lingkungan. Paling luar adalah daerah penunjang III yang meliputi area jagang dan jalan besar di sekelilingnya serta satu lapis persil disisi luarnya. Wilayah ini diarahkan sebagai area transisi yang membatasi sekaligus menjembatani Kawasan Kraton Yogyakarta dengan wilayah luar. Langkah penataannya meliputi pengaturan pemanfaatan ruang, kepadatan bangunan, tinggi bangunan dan penampilan bangunan.

\section{2) RenCANA TATa BangunaN DAN LINGKUNGAN KAWASAN KRATON YOGYAKARTA}

Secara umum penataan bangunan di dalam Kawasan Kraton Yogyakarta tidak bisa dilakukan generalisasi pada seluruh bagian wilayahnya karena masing-masing mempunyai karakteristik yang cukup spesifik. Arahan lebih banyak diaplikasikan menurut penggal jalan tertentu ataupun area yang terbatas. Secara umum disiratkan juga

perlunya pelestarian elemen ruang kawasan. Di luar kompleks kraton, keberadaan Pasar Ngasem juga perlu mendapatkan perhatian khusus terlebih bila akan membuka akses ke situs Tamansari. Dalam hal penanganan lingkungan perumahan ditujukan pada peningkatan kualitas perumahan yang sudah ada maupun pertumbuhan baru, serta mengendalikan pertumbuhan pada area khusus. Ada tiga hal yang direncanakan:

a. Penanganan pola lingkungan perumahan, yaitu dengan menerapkan syarat teknis bagi 
perumahan yang sudah ada, serta pengaturan pola jalan dan perletakan fasilitas lingkungan bagi perumahan baru.

b. Pengendalian kualitas lingkungan. Hal ini dilakukan dengan penyediaan jaringan utilitas, serta pengendalian kualitas lingkungan.

c. Pengendalian bangunan. Hal ini dilakukan melalui bentuk pengaturan yang berkaitan dengan aspek Koefisien Dasar Bangunan, Koefisien Lantai Bangunan , tinggi bangunan maupun orientasi bangunan.

\section{c. KeAdAAN TATA RUANG DAN BANGUNAN}

Tata ruang dan prasarana yang ada di Kawasan Cagar Budaya Kraton Yogyakarta, tidak dapat dilepaskan dari keberadaan Kraton Kasultanan Yogyakarta yang berperan sebagai bekas pusat pemeritahan dan sebagai tempat tinggal raja-raja dari Kasultanan Yogyakarta. Kompleks Kraton Kasultanan Yogyakarta berorientasi ke arah utara. Bangunan Kraton Kasultanan Yogyakarta terletak di pusat Kota Yogyakarta, dan sekarang merupakan bagian dari wilayah Kecamatan Kraton. Kecamatan Kraton pada sisi utara berbatasan dengan

Kecamatan Gondomanan, sisi timur berbatasan dengan Kecamatan Mergangsan, sisi selatan berbatasan dengan Kecamatan Mantrijeron, dan sisi barat berbatasan dengan Kecamatan Wirobrajan. Kecamatan Kraton dibatasi oleh Beteng Kraton Yogyakarta yang berbentuk segi empat dengan sedikit variasi bentuk pada sisi utara. Ukuran keliling dari beteng ini adalah 4 kilometer. Beteng Kraton Yogyakarta memiliki lima buah pintu gerbang serta empat buah tempat pengintaian yang disebut tolak tala atau bastion pada keempat sudutnya. Kelima pintu gerbang tersebut adalah:

1)Pintu gerbang (plengkung) di Ngasem, disebut sebagai Jagasurat.

2) Pintu gerbang di Tamansari, disebut sebagai Jagabaya.

3)Pintu gerbang di Gading, disebut Nirbaya.

4)Pintu gerbang di Suryomentaraman diberi nama Madyosuro. Pintu gerbang ini terkenal dengan nama Plengkung Buntet.

5)Pintu gerbang di Mijilan, diberi nama Tarunasura, yang berarti pemuda yang berani. Dari kelima pintu gerbang ini, yang hingga kini masih berbentuk plengkung dan kondisinya relatif masih baik hanyalah tinggal pintu gerbang Nirbaya di sisi selatan, dan Tarunasura di sisi utara. Benda cagar budaya yang berada di kawasan inti, daerah penunjang-I, daerah penunjang-II dan daerah penunjang-III, termasuk di dalam rencana penanganan preservasi adaptif. Dalam pengertian benda cagar budaya, bangunan yang berada di Kawasan Cagar Budaya Kraton Yogyakarta, Kraton Kasultanan Yogyakarta dan Tamansari dapat dikategorikan sebagai benda cagar budaya tidak bergerak yang berupa bangunan peninggalan budaya. Sedangkan bangunan peninggalan budaya pendukung lainnya yang terdiri atas: perlengkapan fasilitas Kraton,

dalem Pangeran, rumah abdi dalem, gapura, dan masjid dapat dimasukkan dalam kategori cagar budaya, karena usianya telah melebihi limapuluh tahun. Aset cagar budaya yang ada di Kawasan Cagar Budaya Kraton Yogyakarta, terdiri atas: Kraton Kasultanan Yogyakarta, Tamansari, perlengkapan fasilitas Kraton sejumlah tiga belas bangunan, dalem Pangeran sejumlah sembilan belas bangunan, dan rumah abdi dalem sejumlah lima bangunan.

1) Kraton Kasultanan Yogyakarta: 
Kompleks Kraton Kasultanan Yogyakarta secara garis besar dibagi dalam tiga halaman yang membujur dari utara ke selatan. Halaman tersebut dibagi lagi menjadi halaman yang lebih kecil dengan beberapa bangunan di dalamnya. Seluruh bangunan yang terdapat di halaman utama Kraton Kasultanan Yogyakarta mempunyai arah hadap ke timur, kecuali dalem Prabayeksa sebagai inti pusat raton mempunyai arah hadap ke selatan. Kasultanan Yogyakarta mempunyai dua alun-alun, yaitu Alun-alun Utara, dan Alun-alun Selatan. Di sisi barat dari Alun-alun Utara terdapat Masjid Agung. Alun-alun Utara, merupakan sebidang tanah lapang yang terletak di muka Kraton (sisi utara) dengan ukuran $150 \mathrm{x}$ 150 meter, berfungsi sebagai tempat penyelenggaraan upacara kerajaan.

Masjid Agung, terletak di sebelah barat Alun-alun Utara. Pintu gerbangnya berbentuk limasan semar tinandu, sedangkan bangunan Masjid Agung berbentuk tajuk lambang teplok yang beratap susun tiga, dengan serambi berbentuk limasan lawakan beratap dua, di sekelilingnya penuh dengan air. Selain berfungsi sebagai tempat ibadah, dahulu juga berfungsi sebagai pelaksanaan pengadilan agama dan musyawarah para pemimpin agama.

Halaman pertama Kraton Kasultanan Yogyakarta dibagi dalam tiga bagian,

yaitu Sitihinggil Utara, Kemandungan Utara, dan Sri Manganti.

Halaman kedua Kraton terdiri atas tiga bagian, yaitu halaman utama Kraton bagian tengah, halaman utama Kraton bagian barat yang disebut sebagai Keputren, dan halaman utama bagian timur yang disebut Kesatriyan

Halaman ketiga Kraton terdiri atas tiga bagian, yaitu halaman Kemagangan, halaman Kemandhungan
Selatan, dan halaman Sitihinggil Selatan.

2) Tamansari: dibangun bersamaan dengan pembuatan beteng keliling dan Masjid Agung, berfungsi sebagai tempat rekreasi Sri Sultan beserta keluarganya. Beberapa bagian dari bangunan Tamansari ini telah banyak yang hilang. Beberapa bagian yang masih menunjukkan kenampakan yang jelas meliputi zona kolam dan sekitarnya, zona sekitar Sumur Gemuling, zona sekitar Pulau Kenanga, dan zona sekitar Pasarean Ledoksari. Tidak adanya pola tata ruang yang jelas di Kawasan Tamansari berakibat apda munculnya konflik-konflik penggunaan ruang. Konflik yang terjadi adalah zona di sekitar Pasar Burung Ngasem, berupa konflik transportasi, kegiatan pasar, dan permukiman. Konflik antara transportasi, kegiatan pasar, dan perumahan terjadi di zona sekitar kompleks Balai Teknik Kesehatan Lingkungan Yogyakarta. Konflik antara permukiman, dan kelestarian artefak, terjadi di zona sekitar artefak, khususnya di sekitar Sumur Gumuling, sekitar Pulau Kenanga, sekitar Terowongan, dan sekitar Pasarean Ledoksari. Konflik-konflik yang terjadi tersebut cenderung semakin mengaburkan tampilan yang selama ini masih dapat dikenali, sehingga karakteristik zona yang mempunyai nilai historis tinggi tersebut semakin sulit dikenali lagi.

3) Perlengkapan Fasilitas Kraton, terdiri

atas: Pagongan, Masjid Sela, Muse-um Kereta. Ringin Kurung Utara, Ringin Kurung Selatan, Panggung Krapyak, Pesanggrahan Hamengku Buwono II, Masjid Keben, Pekapalan, SD Keputran, Bangsal Prabeya, Kandang Gajah, dan

Kandang Sima.

Kondisi masing-masing bangunan, sebagai berikut: 
Tabel 3.3

Kondisi Bentuk Bangunan Fasilitas Kraton

\begin{tabular}{|c|c|c|c|c|c|c|c|}
\hline Bangunan & Bentuk & Letak & Pemilik & Penggunaan & $\begin{array}{c}\text { Kondisi/ } \\
\text { Konstruksi }\end{array}$ & Pemeliharaan & Tinggi \\
\hline Pagongan & Limasan & Kauman & Kraton & $\begin{array}{l}\text { Tempat } \\
\text { Gamelan }\end{array}$ & Baik/Permanen & $\begin{array}{l}\text { Pemugaran } \\
1987\end{array}$ & $7,0 \mathrm{~m}$ \\
\hline Masjid Sela & Tajuk & Panembahan & Kraton & Ibadah & Cukup/Permanen & $\begin{array}{l}\text { Penambahan } \\
1967\end{array}$ & $8,0 \mathrm{~m}$ \\
\hline $\begin{array}{l}\text { Museum } \\
\text { Kereta }\end{array}$ & Limasan & Kadipaten & Kraton & $\begin{array}{l}\text { Museum } \\
\text { Kereta }\end{array}$ & Cukup/Permanen & $\begin{array}{l}\text { Pemugaran } \\
1986\end{array}$ & $10,8 \mathrm{~m}$ \\
\hline $\begin{array}{l}\text { Ringin Kurung } \\
\text { Utara }\end{array}$ & - & $\begin{array}{l}\text { Alun-Alun } \\
\text { Utara }\end{array}$ & Kraton & - & Baik/Permanen & - & $2,5 \mathrm{~m}$ \\
\hline $\begin{array}{l}\text { Ringing Kurung } \\
\text { Selatan }\end{array}$ & - & $\begin{array}{l}\text { Alun-2 } \\
\text { Selatan }\end{array}$ & Kraton & - & Baik/Permanen & - & $2,5 \mathrm{~m}$ \\
\hline $\begin{array}{l}\text { Panggung } \\
\text { Krapyak }\end{array}$ & Panggung & Krapyak & Kraton & - & Baik/Permanen & - & $8,5 \mathrm{~m}$ \\
\hline $\begin{array}{l}\text { Pesanggrahan } \\
\text { HB II }\end{array}$ & Dinding & Panembahan & Samiyun & $\begin{array}{l}\text { Rumah } \\
\text { Tinggal }\end{array}$ & Rusak/Permanen & Tidak Ada & $8,0 \mathrm{~m}$ \\
\hline Masjid Keben & Tajuk & Kadipaten & Kraton & Ibadah & Baik/Permanen & - & $8,5 \mathrm{~m}$ \\
\hline Pekapalan & Joglo & Ngupasan & Kraton & Perkantoran & Baik/Permanen & - & $6,5 \mathrm{~m}$ \\
\hline SD Keputran & Limasan & Panembahan & Kraton & Pendidikan & Baik/Permanen & $\begin{array}{l}\text { Pemugaran } \\
1980\end{array}$ & $7,0 \mathrm{~m}$ \\
\hline $\begin{array}{l}\text { Bangsal } \\
\text { Prabeya }\end{array}$ & Joglo & Panembahan & Kraton & $\begin{array}{l}\text { Pondok } \\
\text { Pramuka }\end{array}$ & Baik) Permanen & $\begin{array}{l}\text { Pemugaran } \\
1976\end{array}$ & $7,5 \mathrm{~m}$ \\
\hline $\begin{array}{l}\text { Kandang } \\
\text { Gajah }\end{array}$ & Limasan & Patehan & Kraton & $\begin{array}{l}\text { Rumah } \\
\text { Tinggal }\end{array}$ & Cukup/Permanen & $\begin{array}{l}\text { Pemugaran } \\
1988\end{array}$ & $6,0 \mathrm{~m}$ \\
\hline Kandang Sima & Joglo & $\begin{array}{l}\text { Alun-Alun } \\
\text { Utara }\end{array}$ & Kraton & Ibadah & Baik/Permanen & $\begin{array}{l}\text { Pemugaran } \\
1987\end{array}$ & $5,0 \mathrm{~m}$ \\
\hline
\end{tabular}

Sumber: Survei Lapangan dan Pengolahan Studio, 2010

Masing-masing bangunan cenderung dengan konstruksi lantai tegel, dinding tembok, rangka atap kayu, dan penutup atap genting. Prasarana bangunan cenderung dilengkapi dengan air bersih, listrik, tempat sampah, kamar mandi, dan sebagian dilengkapi dengan sumur air bersih.

4) Dalem Pangeran, terdiri atas: Dalem Purbonegaran, Dalem Mangkubumen, Dalem Ngadiwinatan, Dalem Suryoputran, Dalem Notoprajan, Dalem Mangunkusuman, Dalem Condrodiningratan, Dalem Kaneman, Dalem Pujokusuman, Dalem Mangkudiningratan, Dalem Puspodiningratan, Dalem Joyokusuman (Magangan Wetan), Dalem Pakuningratan, Dalem Tejokusuman, Dalem Yudonegaran, Dalem Suryonegaran, Dalem Benawan, Dalem Joyokusuman (Bintaran/Rotowijayan), dan Dalem Suryobratan. Bangunan cenderung dengan kostruksi lantai tegel, dinding tembok pada beberapa bagian bangunan dengan gebyok, rangka atap kayu, dan penutup atap dari genting.
5) Permukiman dan kegiatan usaha di Daerah Penunjang-I: Sejalan dengan arahan agar lingkungan yang berkembang di Kawasan Inti diaarahkan dapat berorientasi pada bangunan Kraton, maka penanganan dalam bentuk preservasi adaptif dilakukan dengan melakukan preservasi pada bangunbangunan yang ada di Kawasan Penunjang-I, baik yang berupa bangunan penunjang, fasilitas Kraton, dalem Pangeran, dan abdi dalem Kraton, dan bangun-bangunan lain yang berkembang kemudian dengan ciri bangunan tradisional yang bernafaskan bangunan cagar budaya di Kawasan Cagar Budaya Kraton Yogyakarta.

Kondisi bangunan, lingkungan, dan prasarana bangunan yang ada di Kawasan ini cenderung masih terkendali.

6) Permukiman dan kegiatan usaha di Daerah Penunjang-II: Kedudukannya sebagai kawasan pemukiman dan pelayanan lingkungan yang bersifat lokal, menunjukkan perkembangan yang tidak terkontrol. Perkembangan ini 
7) tidak saja oleh kegiatan dalam menunjang kegiatan wisata (lingkungan Dagadu), namun beberapa kegiatan lain sepeti pasar (Ngasem), industri rumah tangga (di sekitar Tamansari) semakin menunjukkan gejala tidak memenuhi upaya menjaga kelestarian budaya dan kualitas lingkungan.

8) Rumah Tinggal di Daerah Penunjang-III : Hampir seluruh bangunan yang ada di daerah bekas jagang telah dibangun dalam bentuk bangunan bertingkat lebih dari satu lantai, baik untuk keperluan rumah tinggal, dan sebagian besar untuk kegiatan usaha.

Lingkungan permukiman dan usaha yang berkembang tidak terkendali ini pada sisi utara timur menjadi lingkungan yang tidak lagi memenuhi kualitas lingkungan yang baik.

9) Rumah Abdi Dalem, terdiri atas: Rumah Abdi Dalem Pengulon, Rumah Abdi Dalem Benawan, Rumah Abdi Dalem Kori, Rumah Abdi Dalem Madukusuman,dan Rumah Abdi Dalem Juru Sungging.

10) Bangunan cenderung dengan konstruksi lantai tegel, untuk dinding sebagian besar tembok dan kayu jati, rangka atap akyu jati, dan penutup atap genting. Prasarana bangunan dilengkapi dengan air bersih, listrik, tempat sampah, km/wc, dan sumur air bersih.

Sebagian bangunan yang berbentuk joglo, dilengkapi dengan pendopo.

\section{d. TRANSPORTASI DAN PRASARANA}

Sebagai konsekuensi logis dari ciri kota dengan predikat sebagai kota budaya dan pariwisata, maka Kawasan Cagar Budaya Kraton Yogyakarta menjadi tujuan utama bagi wisatawan

domestik maupun mancanegara. Berdasarkan identifikasi awal sistem kegiatan yang menjadi penyerap perjalanan yang berada di Kawasan
Kraton Yogyakarta dibedakan menjadi:

- Pusat kegiatan wisata

- Pusat kegiatan perdagangan

- Pusat kegiatan usaha dan jasa Intensitas kegiatan tersebut akan terjadi peningkatan sesuai dengan liburan sekolah maupun hari libur nasional. Pusat kegiatan lain yang sebenarnya terkait dengan pusat kegiatan wisata adalah pusat perdagangan di kawasan jalan Malioboro.

1) Sistem Arus Lalulintas dan Jaringan $\underline{\text { Jalan }}$

Jaringan jalan yang ada di Kawasan Kraton Yogyakarta ditinjau dari sisi kualitas perkerasannya sudah cukup baik. Jenis perkerasan yang digunakan umumnya adalah jenis beton aspal. Permasalahan yang muncul adalah konflik yang terjadi antara kegiatan parkir di badan jalan dengan arus lalulintas kendaraan.

2). Parkir Kendaraan

Parkir di sekitar kawasan wisata kraton dapat dibedakan menjadi dua jenis, yaitu: Parkir bagi pengunjung pasar atau kawasan perdagangan lainnya dengan lokasi di jalan Polowijan, Ngasem, Rotowijayan, dan Sompilan serta parkir bagi kendaraan pengunjung wisata dengan lokasi di luar badan jalan. Kantong parkir Ngabean ditinjau dari lokasinya agak jauh dari alun-alun utara, sehingga ada keengganan bagi pengunjung untuk berjalan kaki.. 
Tabel 3.5

Aktivitas Parkir Kendaraan di Jalan Polowijan pada Hari Minggu

\begin{tabular}{|c|c|c|c|c|c|c|c|c|}
\hline \multirow{2}{*}{$\begin{array}{ll}\text { a) } & \text { Int } \\
& \text { er } \\
& v a \\
& l\end{array}$} & \multicolumn{4}{|c|}{ Masuk } & \multicolumn{2}{|r|}{ (1) } & \multicolumn{2}{|c|}{ Keluar } \\
\hline & SM & MP & Bck & Spd & SM & MP & Bck & Spd \\
\hline $06.00-07.00$ & 228 & 9 & 30 & 39 & 109 & 7 & 32 & 42 \\
\hline $07.00-08.00$ & 311 & 16 & 23 & 29 & 246 & 10 & 23 & 29 \\
\hline $08.00-09.00$ & 302 & 16 & 24 & 20 & 213 & 11 & 24 & 20 \\
\hline $09.00-10.00$ & 228 & 13 & 15 & 22 & 189 & 21 & 15 & 22 \\
\hline $10.00-11.00$ & 195 & 11 & 12 & 19 & 181 & 7 & 12 & 14 \\
\hline $11.00-12.00$ & 192 & 8 & 20 & 29 & 180 & 7 & 20 & 29 \\
\hline $12.00-13.00$ & 205 & 13 & 31 & 17 & 194 & 11 & 30 & 14 \\
\hline $13.00-14.00$ & 216 & 17 & 19 & 22 & 188 & 18 & 16 & 22 \\
\hline $14.00-15.00$ & 99 & 9 & 12 & 9 & 114 & 12 & 7 & 9 \\
\hline $15.00-16.00$ & 17 & 4 & 4 & 1 & 26 & 2 & 2 & 0 \\
\hline
\end{tabular}

Sumber: Survei dan Pengolahan Studio, 2010

Tabel 3.6

Aktivitas Parkir Kendaraan di Jalan Ngasem pada Hari Minggu

\begin{tabular}{||c|c|c|c|c|c|c|c|c||}
\hline \multirow{2}{*}{$\begin{array}{c}\text { Interval } \\
\text { waktu }\end{array}$} & \multicolumn{4}{|c|}{ Masuk } & \multicolumn{5}{c||}{ Keluar } \\
\cline { 2 - 10 } SM & MP & Bck & Spd & SM & MP & Bck & Spd \\
\hline $06.00-07.00$ & 54 & 17 & 3 & 11 & 36 & 10 & 5 & 10 \\
\hline $07.00-08.00$ & 91 & 29 & 22 & 21 & 83 & 29 & 20 & 16 \\
\hline $08.00-09.00$ & 89 & 20 & 31 & 21 & 78 & 23 & 22 & 17 \\
\hline $09.00-10.00$ & 100 & 23 & 40 & 14 & 91 & 16 & 43 & 19 \\
\hline $10.00-11.00$ & 98 & 15 & 40 & 21 & 83 & 17 & 38 & 20 \\
\hline $11.00-12.00$ & 77 & 18 & 31 & 7 & 76 & 18 & 38 & 11 \\
\hline $12.00-13.00$ & 48 & 33 & 11 & 0 & 31 & 20 & 8 & 1 \\
\hline $13.00-14.00$ & 49 & 19 & 27 & 0 & 50 & 24 & 23 & 0 \\
\hline $14.00-15.00$ & 26 & 14 & 12 & 0 & 32 & 18 & 13 & 0 \\
\hline $15.00-16.00$ & 10 & 10 & 0 & 0 & 16 & 12 & 4 & 0 \\
\hline
\end{tabular}

Sumber: Survei dan Pengolahan Studio, 2010 
Berdasarkan kedua tabel tersebut, nampak bahwa jenis kendaraan yang parkir di ruas Jl. Polowijan maupun $\mathrm{Jl}$. Ngasem didominasi oleh kendaraan sepeda motor dengan intensitas yang tinggi pada interval waktu pukul 07.00 hingga pukul 11.00. Kegiatan parkir ini juga diwadahi di daerah Sompilan maupun Jl. Kauman.

2. Pola Penggunaan Lahan

Perubahan pola penggunaan lahan di dalam Kawasan Cagar Budaya Kraton Yogyakarta sebagai dampak dari semakin tingginya citra Kota Yogyakarta sebagai kota wisata dan budaya secara keseluruhan. Berbagai sektor usaha dan jasa maupun perdagangan tumbuh dengan pesat, apabila tidak diantisipasi, maka akan berdampak pada beban arus lalulintas yang harus dilayani dan secara sosial akan merugikan penduduk yang berada di dalam kawasan.

e. SOSIAL DAN EKONOMI MASYARAKAT

Kegiatan sosial dan ekonomi yang tumbuh di Kawasan Cagar Budaya Kraton Yogyakarta didukung oleh perkembangan sosial ekonomi karena keberadaan sektor pariwisata.

1) Sosial ekonomi yang tumbuh dari masyarakat: Kondisi ini didasarkan pada kenyataan, bahwa masyarakat di Kawasan Cagar Budaya Kraton Yogyakarta berada pada golongan ekonomi menengah ke bawah. Beberapa masyarakat yang berada pada golongan ekonomi menengah ke atas cenderung berada pada sisi luar kawasan (khususnya Kawasan
Penunjang-III) yang memiliki akses langsung dengan kegiatan perekonomian di luar Kawasan Cagar Budaya Kraton Yogyakarta. Beberapa potensi yang diharapkan mampu meningkatkan sosial dan ekonomi masyarakat di Kawasan Cagar Budaya Kraton Yogyakarta, meliputi: lokasinya yang strategis karena berada pada pusat Kota Yogyakarta, kedudukannya sebagai salah satu daerah tujuan wisata, keberadaan tenaga trampil dan berpengalaman dalam bidang seni dan budaya yang diharapkan mampu menunjang industri pariwisata, berkembangnya produk spesifik Yogyakarta sehingga mampu menjadi komoditi unggulan sebagai cinderamata yang khas. Peluang yang diharapkan dapat memberikan motivasi dalam peningkatan dan pengembangan sosial ekonomi yang tumbuh dari masyarakat dimungkinkan muncul dari: semakin berkembangnya kegiatan pariwisata, kepedulian dan keberpihakan pemerintah terhadap kegiatan sosial ekonomi yang tumbuh dari masyarakat, keberadaan beberapa institusi (khususnya pendidikan) yang diharap mampu menunjang kualitas sosial dan ekonomi masyarakat, dan otonomi yang nantinya akan dilimpahkan oleh pemerintah pusat pada pemerintah daerah.

2)Sosial ekonomi yang berkembang dari kegiatan pariwisata: Kondisi ini didasarkan pada keberadaan situs peninggalan sejarah dan purbakala dan berbagai kegiatan seni budaya yang berkembang, 
yang memungkinkan tumbuh sebagai asset yang menunjang.

\subsection{Arahan bagi Peraturan Bangunan Khusus}

Dari hasil kajian sebelumnya, beberapa arahan bagi tersusunnya Peraturan Bangunan Khusus (PBK) pada Kawasan Cagar Budaya Kraton Yogyakarta.

\section{a. Ketentuan Umum}

Sebagai suatu Peraturan Bangunan Khusus seharusnya memberikan pengertian dan batasan dasar atas halhal yang akan dibicarakan kemudian, yaitu:

\section{1) Pengertian Umum}

Berisi tentang batasan-batasan dasar yang akan dipergunakan lebih lanjut didalam PBK ini, beberapa hal pokok yang harus dijadikan pemahamam dasar antara lain sebagai berikut:

a) Kraton adalah Kraton Yogyakarta yang merupakan organisasi kelembagaan budaya sebagai penerus pemerintahan Kasultanan Ngayogyakarta Hadiningrat dimasa lalu (pra kemerdekaan).

b) Kawasan Cagar Budaya Kraton Yogyakarta, adalah keseluruhan wilayah Kecamatan Kraton dan ruas Jalan Brigjen Katamso, Jalan MT.Haryono, dan Jalan Notoprajan, sampai dengan jarak satu persil, atau seratus meter dari tepi jalan yang mengelilingi beteng Kraton.

c) Pemerintah Daerah, adalah Pemerintah Kota Yogyakarta.

d) Dewan Dewan Perwakilan Rakyat, adalah Dewan Perwakilan Rakyat Kota Yogyakarta.

e) Kepala Daerah, adalah Walikota Yogyakarta.

f) Dinas Tata Kota, adalah Dinas Tata Kota Kota Yogyakarta, yang mempunyai kewenangan untuk penataan bangunan baik secara teknik maupun pekerjaan umumnya yang berada di Kota Yogyakarta.

g) Kawedanan Hageng Punokawan (KHP) Wahana Saptakriya, adalah lembaga yang secara khusus dibentuk oleh Kraton, yang mempunyai kewenangan untuk memberi pertimbangan terhadap pembangunan yang ada di Kawasan Cagar Budaya Kraton Yogyakarta.

h) Panitikismo adalah lembaga yang secara khusus dibentuk oleh Kraton yang mempunyai wewenang untuk mengurusi masalah pertanahan yang statusnya dibawah kepemilikan Kraton.

i) Kantor Purbakala adalah kantor instansi teknis yang mengurusi benda bersejarah, purbakala dan bernilai arkeologis.

j) Bangunan, adalah setiap susunan sesuatu yang berdiri dan melekat pada tanah, atau bertumpu pada batu landasan, dengan susunan yang dirancang sehingga membentuk suatu ruangan yang mempunyai batas yang jelas baik sebagian, maupun seluruh sisinya.

k) Bangunan, adalah bentuk bangunan yang di dalamnya dapat tersusun atas kamar, kamar mandi, kakus, ruang untuk kegiatan usaha, dan gudang.

1) Persil, adalah suatu perpetakan tanah yang terdapat dalam suatu rencana kota, yang menurut pertumbangan dapat digunakan untuk mednirikan suatu bangunbangunan.

m) Pekarangan, adalah bagian ruang terbuka dari suatu persil, di luar bangunan yang telah mengisi, maupun pada saatnya mengisi bagian persil tersebut.

n) Perda Bangunan adalah Peraturan Daerah Kotamadya Daerah Tingkat II Yogyakarta No.4 Tahun 1988 tentang Bangunan yang mengatur tertib pembangunan di 
dalam wilayah yurisdiksi administrasinya.

2) Klasifikasi Bangunan

Bangunan didalam Kawasan Cagar Budaya Kraton Yogyakarta pada dasarnya dapat dikategorikan menurut penggunaannya, jenis konstruksinya, umurnya, langgam arsitektur, lokasi, kepemilikan, serta nilai warisan budayanya .

a) Bangunan menurut penggunaannya, dibagi atas:

- Bangunan Perumahan; Fasilitas Umum; Perdagangan \& Jasa; pendidikan; kelembagaan;

- Bangunan Campuran.

Dalam Peraturan Bangunan Khusus ini, yang dimaksud dengan Bangunan perumahan, adalah rumah, atau sekumpulan rumah baik yang berfungsi sebagai rumah tinggal yang berdiri sendiri, rumah gandeng. Dalem pangeran yang difungsikan sebagai hunian, maupun rumah campuran untuk kegiatan yang sesuai dengan lingkungan perumahan.

Bangunan fasilitas umum, adalah bangunan yang mempunyai fungsi bagi kepentingan umum dalam skala tertentu, lingkungan, lokal, regional, maupun nasional. Bangunan fasilitas umum terdiri atas: bangunan peribadatan, gedung pertemuan, perpustakaan, museum dan pameran seni, gedung olahraga, stasiun, gedung kesenian, kesehatan, sekolahan, dan gedung serbaguna lain yang berfungsi sebagai tempat berkumpulnya masyarakat, termasuk bangunan pendidikan dan kelembagaan.

Bangunan perdagangan dan Jasa, adalah bangunan atau bagian bangunan yang dengan ijin dari instansi yang berwenang terdaftar sebagai tempat pelayanan perdagangan dan jasa. Jenis bangunan ini dapat berupa toko, pertokoan, warung, rumah makan, perbankan, bengkel, jasa usaha lain.

Bangunan kantor, adalah bangunan yang diperuntukkan bagi kepentingan pengelolaan administrasi kepemerintahan. Untuk Kawasan Cagar Budaya Kraton Yogyakarta berupa Kantor Kecamatan, Kelurahan, Kelembagaan Kraton, Yayasan.

Bangunan industri, adalah bangunan atau bagian dari bangunan yang berfungsi sebagai tempat diproduksinya suatu barang dan atau bahan-bahan. Skala industri yang diperkenankan di dalam Kawasan Cagar Budaya Kraton Yogyakarta adalah industri rumah tangga dan industri kecil rumahan.

Bangunan gudang, adalah bangunan atau bagian dari bangunan yang digunakan sebagai tempat penyimpanan barang, dan atau untuk pameran barang dan atau untuk penjualan barang.

Bangunan campuran, adalah bangunan yang mewadahi berbagai fungsi kegiatan.

b) Bangunan menurut jenis konstruksinya.

- Bangunan Permanen 1;

- Bangunan Permanen 2;

- Bangunan Semi Permanen 1;

- Bangunan Semi Permanen 2;

- Bangunan Sementara/Temporer.

Klasifikasi bangunan ini adalah berdasar pada sistem kontruksi yang dipergunakan, bukan pemanfaatannya.

c) Bangunan Menurut Umurnya

- Bangunan kuno dibangun lebih dari 50 tahun ;

- Bangunan lama dibangun kurang dari 50 tahun lalu sampai 20 tahun

- Bangunan baru dibagun setelah 20 tahun lalu.

Pengambilan jangka waktu 50 tahun dalam kategorisasi 
Bangunan Kuno sifatnya tentatif dan relatif.

d) Bangunan Menurut Lokasinya

- Bangunan di tepi jalan utama;

- Bangunan di tepi jalan lingkungan;

- Bangunan di tepi gang kampung;

- Bangunan tanpa akses jalan.

Lokasi bangunan dapat dipilahkan atas jalan yang kemudahan aksesnya. Ini ditunjukkan oleh kelas jalan yang berhubungan.

Kategori jalannya sendiri mengacu pada ketentuan rencana tata ruang dan RTBL setempat.

e) Bangunan Menurut Kepemilikannya

- Bangunan milik kerabat Kraton;

- Bangunan milik abdidalem Kraton;

- Bangunan milik keluarga abdidalem Kraton;

- Bangunan milik perseorangan umum/masyarakat;

- Bangunan milik pemerintah.

Di lapangan dimungkinkan adanya kasus dimana bangunan yang secara historis-kultural mempunyai kaitan yang sangat erat dengan Kraton, dimiliki oleh orang lain yang tidak ada hubungan kekerabatan apapun. Apalagi dalam era demokrasi ini, secara hukum siapapun dapat memiliki aset di dalam Kawasan Cagar Budaya Kraton Yogyakarta.

Dengan adanya kategorisasi ini maka dapat dilakukan pengendalian kepemilikan di dalam Kawasan Cagar Budaya Kraton Yogyakarta. Maksudnya adalah untuk menunjang upaya preservasi kawasan. Karena pada intinya yang dipreservasi adalah aspek budayanya, logikanya kehidupan sosialnya pun perlu dipreservasi juga.

f) Bangunan Menurut Langgam Arsitekturnya
- Bangunan Tradisional Jawa;

- Bangunan Bercorak Tradisional Jawa;

- Bangunan Vermakular/Kampung;

- Bangunan Modern.

Bangunan tradisional Jawa adalah bangunan yang merupakan bangunan kuno atau lama yang menggunakan corak tradisional. Ini berbeda dengan kategorisasi kedua yang hanya memiliki corak tradisional tapi bisa berupa bangunan baru.

g) Bangunan Menurut Nilai Warisan Budayanya.

- Bangunan Warisan Utama (1);

- Bangunan Warisan (2);

- Bangunan Biasa.

Bangunan Warisan Utama, selain artifak dan situs-situs arkeologis, dapat dicontohkan adalah Dalem Pangeran dan masjid kuno. Bangunan Warisan adalah beberapa bangunan rumah kuno selain bangunan warisan utama, namun memiliki nilai kesejarahan dan budaya (heritage value) yang signifikan. Sedangkan bangunan biasa adalah bangunan yang tidak memiliki nilai warisan budaya.

b. PenataAn Bangunan

Kawasan Cagar Budaya Kraton Yogyakarta memiliki berbagai macam potensi sebagai berikut :

1) Lokasi mudah dicapai dan terkait dengan kawasan budaya lainnya

khususnya Kraton Yogyakarta

2) Merupakan bagian yang penting dan tak terpisahkan dari kesatuan Kawasan Kraton Yogyakarta.

3) Merupakan suatu kawasan yang unik

4) Beberapa elemen artefak masih cukup nampak untuk menunjukkan gambaran kondisi asli kawasan. 
5) Merupakan kawasan dengan guna lahan campuran yang menarik dan revable.

6) Pada beberapa kawasan daya dukungnya masih dapat ditingkatkan.

Beberapa permasalahan yang muncul di Kawasan Cagar Budaya Kraton Yogyakarta yang perlu mendapatkan arahan penataan dan penanganan agar tujuan disusunnya penataan bangunan khusus di Kawasan Cagar Budaya Kraton Yogyakarta dapat berjalan, meliputi:

1) Menurunnya karakteristik tata ruang pada Kawasan Cagar Budaya Kraton Yogyakarta.

2) Tidak adanya pola tata ruang yang jelas.

3) Kaburnya bagian kawasan yang mempunyai nilai historis.

4) Peningkatan kegiatan baru di Kawasan Kraton Yogyakarta yang kurang terkontrol.

5) Intervensi kegiatan permukiman pada zona historis dan ruang terbuka pada beberapa artefak

6) Munculnya kegiatan yang berpotensi mencemari lingkungan.

7) Kaburnya batas hak pemilikan dan penggunaan tanah.

Dari potensi yang ada di Kawasan Cagar Budaya Kraton Yogyakarta, arahan bentuk penataan bangunan sebagai landasan dari disusunnya Peraturan Bangunan Khusus di dasarkan pada :

1) Peruntukan Lahan :

a) Secara umum Kawasan Cagar Budaya Kraton Yogyakarta dengan batas dinding beteng ditetapkan sebagai Kawasan Cagar Budaya.

b) Bangunan Kraton Kasultanan Yogyakarta sebagai inti kawasan, dan Tamansari ditetapkan sebagai daerah preservasi dengan aktivitas budaya sebagai obyek wisata kultural dan sumber informasi budaya.

c) Dalem Pangeran diharapkan dapat mendapatkan subsidi pendanaan secara mandiri agar pemeliharaan dan pelestarian bangunan tetap dapat belangsung.

d) Perumahan dan perdagangan dengan skala sedang tetap dijaga komposisinya.

e) Kegiatan perdagangan dengan skala sedang yang memberi kenampakan fasilitas kawasan ditetapkan berkembang di kawasan sepanjang Jalan Yudonegaran, Jalan Kauman, Jalan KH.Agus Salim, dan Jalan Ngasem, dalam bentuk area pelayanan umum, berupa kios, toko, dan warung.

f) Intensitas kegiatan perdagangan di Pasar Ngasem perlu dipertimbangkan kembali, sehingga tidak menyebabkan intervensi kegiatan perdagangan dan parkir ke area perumahan di sekitarnya, melalui alternatif pengembangan pelayanan pasar (khususnya pasar burung) ke luar Kawasan Cagar Budaya Kraton Yogyakarta.

g) Kegiatan perdagangan dengan skala regional/kota, yang terbentuk di sepanjang Jl.Brigjen.Katamso, Jl.MT.Haryono, \& J1.KH.Wahid Hasyim.

h) Kegiatan industri rumah tangga dan perdagangan dalam bentuk pertokoan yang menjual cinderamata, kelontong, dan persewaan pakaian ditetapkan agar skala kegiatannya tidak berkembang terlalu jauh, sehingga mengganggu lingkungan di sekitarnya.

i) Secara umum kepadatan 
bangunan

(khususnya

perumahan di sekitar situs

Tamansari) perlu dijaga, sedangkan infra struktur perlu ditangani lebih intensif.

2) Nilai Intensitas:

Berdasarkan tingkat strategis beberapa area yang ada di Kawasan Cagar Budaya Kraton Yogyakarta, beberapa area memerlukan penganan yang khusus, meliputi:

a) Area sekitar Alun-Alun Utara dan Selatan (termasuk di dalamnya pusat pemerintahan)

b) Area sekitar (nDalem) Kadipaten

c) Area sekitar Kauman

d) Area sekitar (nDalem) Notoprajan

e) Area di sepanjang jalan yang memiliki fungsi komersil dan terbentuk di sepanjang Jalan Brigjen.Katamso, MT.Haryono, dan Jalan Wahid Hasyim.

3) Sistem Hubungan:

a) Sebagai bagian dari upaya penataan sistem transportasi kota yang ada di Kawasan Kraton Yogyakarta, maka penyediaan area parkir akan membantu kelancaran lalulintas.

b) Kawasan Cagar Budaya Kraton Yogyakarta perlu ditunjang dengan perencanaan jalur wisata pedestrian bagi lokasi yang berdekatan dalam kesatuan jalur

c) Memfungsikan area parkir bus wisata di bagian barat Jalan KH.Agus Salim diharapkan dapat mengurangi kepadatan lalau-lintas di Kawasan Cagar Budaya Kraton Yogyakarta dengan menciptakan jalur wisata yang menarik, sejak dari area parkir menuju pada obyekobyek wisata di Kawasan Cagar Budaya Kraton Yogyakarta.
4) Ruang Terbuka dan Tata Hijau: Keberadaan ruang terbuka di Kawasan Cagar Budaya Kraton Yogyakarta ditunjang terutama oleh Alun-alun Utara dan Selatan. perlu arahan penataannya sehingga tetap dapat berfungsi dengan baik sebagai ruang terbuka, khususnya pengembalian fungsi semula setelah digunakan untuk kegiatan-kegiatan rutin Sekaten.

5) Bangunan dan Lingkungan: Upaya penataan bangunan dan lingkungan di Kawasan Cagar Budaya Kraton Yogyakarta, dilakukan melalui penanganan terhadap kondisi obyek sebagai berikut:

a) Perencanaan bangunan, dilakukan melalui upaya:

- pelestarian benda dan bangunan cagar budaya

- perlindungan bagian kawasan

- peremajaan lingkungan yang mendukung warisan budaya

- perbaikan bangunan dan atau lingkungan yang memiliki nilai warisan budaya

- penataan kembali dan atau alih fungsi bangunan dan atau lingkungan yang memiliki nilai warisan budaya

b) Obyek benda dan bangunan yang diarahkan untuk dilestarikan, meliputi:

- Kompleks kraton Kasultanan Yogyakarta, termasuk AlunAlun Utara dan Selatan

- Kompleks Tamansari

- Kompleks Masjid Agung

c) Obyek bagian kawasan yang diarahkan untuk dilindungi:

- Kawasan Kampung PolowijanKadipaten

- Kawasan Kampung Taman

- Kawasan Jalan Ngadisuryan

- Kawasan Jalan H.Agus Salim

- Kawasan Jalan Trikora

- Kawasan Jalan Ibu Ruswo 
- Kawasan Jalan KH.Wahid Hasyim

- Kawasan Jalan Brigjen. Katamso

- Kawasan Jalan Nagan Lor

- Kawasan Jalan Patehan Lor

- Kawasan Jalan Langenastran Lor

- Kawasan Jalan Kemitbumen

- Kawasan Jalan Wijilan

- Kawasan Jalan P. Mangkurat

- Kawasan Jalan Mantrigawen Lor

- Kawasan Plengkung Gading

- Kawasan Jalan MT. Haryono

d) Obyek peremajaan lingkungan permukiman, meliputi:

- Permukiman Kampung Polowijan Taman

- Permukiman Kampung Kriyan, Gebulan, dan Ngadisuryan

- Permukiman Kampung Kadipaten

- Permukiman Kampung Rotowijayan

- Permukiman Kampung Musikanan

- Permukiman Kampung Panembahan

e) Obyek perbaikan terhadap bangunan dan atau lingkungan, meliputi:

- Kompleks Dalem Kanoman

- Kompleks Dalem Sompilan

- Kompleks Dalem Yudonegaran

- Kompleks Dalem Notoprajan

- Kompleks Masjid Batu Panembahan

- Kompleks Museum Sonobudoyo

- Kompleks Plengkung Tamansari

- Kompleks Pojok Beteng Timur Laut

- Kompleks Plengkung Wijilan

- Kompleks Plengkung Gading

- Kompleks Beteng Selatan Bagian Barat

- Kompleks Sasana Hinggil Dwi Abad f) Obyek tindakan alih fungsi pada bangunan, meliputi:

- Kompleks Dalem Mangkubumen

- Kompleks Dalem Notoprajan

- Kompleks Dalem Pakuningratan

- Kompleks Dalem Ngabean

- Kompleks Dalem Kanoman

- Kompleks Dalem Purbayan

- Kompleks Mangkunegaran

- Kompleks Wijilan

Sesuai dengan Rencana Detail Tata Ruang Kota Kota Yogyakarta, ketinggian maksimum bangunan di dalam tembok beteng adalah 7,00 meter. Sedangkan bangunan di luar tembok beteng kurang lebih satu persil di timur 1 . Brigjen.Katamso maksimum 22 meter. Satu persil di selatan Jl.Mayjen. Sutoyo ketinggian maksimum 18 meter, satu persil di selatan Jl.MT.Haryono ketinggian maksimum 18 meter, sedangkan satu persil di sebelah barat JL.KH.Wahid Hasyim maksimum 16 meter.

Lebihlanjut berlaku pula arahan pembangunan sebagaimana telah ditentukan dalam RTBL Kawasan Cagar Budaya Kraton Yogyakarta. Arahan penataan bangunan diarahkan pada beberapa bagian wilayah, dengan mengacu pada ruas jalan yang secara spesifik memerlukan penatan bangunan dengan memberi arah pada:

1) Guna lahan.

2) Gubahan massa.

3) Lansekap.

Arahan penataan bangunan dan lingkungan yang berada di Kawasan Cagar Budaya Kraton Yogyakarta, sebagai berikut:

1) Penataan bangunan Jalan Kauman:

a) Guna lahan:

- Strategi bangunan: pelestarian bangunan tunggal konsolidasi 
bagi status yang tidak sesuai.

- Bangunan: hunian, perdagangan, akomodasi wisata kultural, dan campuran.

- Lahan : hunian, perdagangan, akomodasi wisata kultural, dan campuran.

- Sirkulasi: satu arah, parkir satu sisi.

b) Tata massa:

- Koefisien Lantai Bangunan : 100 $\%$.

- Koefisien Dasar Bangunan : 60 $100 \%$.

- Ketinggian bangunan: untuk hunian, perdagangan, campuran 1 lantai; untuk akomodasi wisata kultural 2 lantai.

- Sempadan : untuk bangunan hunian 1 lantai, 3 meter dari tepi tro-toar; untuk bangunan perdagangan 1 lantai, 5 meter dari tepi trotoar; untuk bangunan 2 lantai 6 meter dari tepi trotoar.

- Fasade: orientasi dan bentuk menyesuaikan ruang jalan memberi citra tradisional.

- Elemen: atap miring atau kombinasi atap tradisional atap pelana dengan tritisan lebar 1,00 - 1,50 meter

c) Lansekap:

- Pagar: diarahkan tanpa pagar pembatas

- Vegetasi: tanaman peneduh dan penghias

2) Penataan Bangun-Bangunan sepanjang Jalan Notoprajan:

a) Guna Lahan:

- Strategi bangunan: pengendalian dan pelestarian bangunan tunggal konsolidasi bagi status yang tidak sesuai alih fungsi

- Bangunan: hunian, perdagangan, akomodasi wisata kultural, dan campuran

- Lahan: hunian, perdagangan, akomodasi wisata kultural, dan campuran

- Sirkulasi: dua arah, parkir satu sisi

a) Tata Massa:

- KLB: $100 \%$

- KDB: 60 - $100 \%$

- Ketinggian bangunan: untuk hunian, perdagangan, campuran 1 lantai; untuk akomodasi wisata kultural maksimum 2 lantai.

- Sempadan: untuk bangunan hunian 1 lantai, 3 meter dari tepi trotoar; untuk bangunan perdagangan 1 lantai, 5 meter dari tepi trotoar; untuk bangunan 2 lantai, 6 meter dari tepi trotoar.

- Fasade: orientasi dan bentuk menyesuaikan ruang jalan memberi citra tradisional

- Elemen: atap miring atau kombinasi atap tradisional atap pelana dengan tritisan lebar 1,00 - 1,50 meter

b) Lansekap:

- Pagar: tanpa pagar

- Vegetasi: tanaman peneduh dan penghias

3) Penataan Bangun-Bangunan sepanjang Jalan Ngasem:

a) Guna Lahan:

- Strategi bangunan: konsolidasi bagi kondisi/status/guna yang tidak sesuai revitalisasi lahan yang kurang dimanfaatkan dengan optimal membagi beban pasar burung keluar Kawasan Cagar Budaya Kraton Yogyakarta

- Bangunan: hunian, perdagangan skala menengah, dan campu-ran

- Lahan: hunian, perdagangan skala menengah, dan campuran

- sirkulasi: satu arah, parkir satu sisi di Jl.Ngasem, parkir sepeda motor di pasar

b) Tata Massa:

- KLB: $100 \%$

- KDB: 60 - $100 \%$

- Ketinggian: 1 lantai untuk hunian, perdagangan, campuran

- Sempadan: untuk bangunan 
hunian, 3 meter dari tepi trotoar

- untuk bangunan campuran dan perdagangan, 5 me-

- ter dari tepi trotoar

- Fasade: orientasi dan bentuk menyesuaikan ruang jalan memberi citra tradisional

- Elemen: atap miring atau kombinasi atap tradisional

- atap pelana dengan tritisan lebar 1,00 - 1,50 meter

c) Lansekap:

- Pagar: tanpa pagar

- Vegetasi: tanaman peneduh dan penghias

4) Penataan Bangun-Bangunan sepanjang Kawasan Jagang:

a) Guna Lahan:

- Strategi bangunan: konsolidasi bagi kondisi/status/guna yang tidak sesuai menekan kemungkinan terjadinya pertumbuhan mengarahkan pertumbuhan yang masih mungkin dilakukan struktur bangunan harus bebas/terpisah dari tembok beteng

- Bangunan: hunian

- Lahan: Hunian

- Sirkulasi: dua arah, parkir dua sisi

b) Tata Massa:

- KLB: -

- KDB: $100 \%$

- Ketinggian: untuk hunian, 1 lantai

- Sempadan: 0,75 dari tepi bangunan terhadap tepi aspal/per-

- kerasan jalan

- Fasade: Citra tradisional, Elemen khas sebagai datum

- Elemen: atap miring atau kombinasi atap tradisional atap pelana dengan tritisan selebar 1,00 - 1,50 meter

c) Lansekap:

- Pagar: tanpa pagar

- Vegetasi: tanaman peneduh dan penghias.
5) Penataan Bangun-Bangunan sepanjang Jl.Brigjen.Katamso:

a) Guna Lahan:

- Strategi bangunan: struktur bangunan yang berhubungan dengan beteng dipisahkan

- Bangunan: komersial, dan campuran

- Lahan: perdagangan, dan campuran

- Sirkulasi: dua arah, parkir dua sisi, disediakan kantong parkir

b) Tata Massa:

- KLB: $150 \%$

- KDB: $75 \%$

- Ketinggian: sisi timur jalan 3 lantai, sisi barat jalan 2 lantai

- Sempadan: untuk perdagangan 12 meter dari as jalan

- Fasade: orientasi dan bentuk menyesuaikan ruang jalan

- Elemen: atap miring, papan reklame, neon sign

c) Lansekap:

- Pagar: tanpa pagar

- Vegetasi: tanaman peneduh

6) Penataan Bangun-Bangunan di sekitar Tamansari:

a) Guna lahan:

- Strategi bangunan: konsolidasi bagi status yang tidak sesuai revitalisasi lahan yang tidak dimanfaatkan optimal adaptip, pemanfaatan kembali yang memungkinkan bagi situs peningkatan utilitas lingkungan

- Bangunan: hunian. dan perdagangan skala menengah (pasar, art shop, galery)

- Lahan: hunian, perdagangan skala menengah

- Sirkulasi: lingkungan, khususnya pedestrian

b) Tata Massa:

- KLB: $100 \%$

- KDB: $60-100 \%$

- Ketinggian: untuk hunian, perdagangan dan campuran, 1 lantai

- Sempadan: 2,00 meter terhadap 
tepi jalan lingkungan

- Fasade: orientasi dan bentuk menyesuaikan ruang jalan memberi citra tradisional.

- elemen: atap miring atau kombinasi atap tradisional atap pelana dengan tritisan selebar 1,00-1,50 meter

c) Lansekap:

- Pagar: permanen atau tanaman

- Vegetasi: tanaman peneduh, penghias, pembatas

7) Penataan Bangun-Bangunan sepanjang Jalan MT.Haryono:

a) Guna Lahan:

- Strategi bangunan: struktur bangunan yang berhubungan dengan beteng dipisahkan

- Bangunan: komersial, dan campuran

- Lahan: Perdagangan dan campuran

- Sirkulasi: dua arah, parkir dua sisi, disediakan kantong parkir

b) Tata Massa:

- KLB: $150 \%$

- KDB: $75 \%$

- Ketinggian: sisi selatan jalan 3 lantai, sisi utara jalan 2 lantai

- Sempadan: 12,00 meter dari as jalan

- Fasade: orientasi dan bentuk menyesuaikan ruang jalan

- Elemen: atap miring, papan reklame, neon sign

c) Lansekap:

- Pagar: tanpa pagar

- Vegetasi: tanaman peneduh

8) Penataan Bangunan di sekitar Alun-Alun Utara:

a) Guna Lahan:

- Strategi bangunan: penataan pedagang kaki-lima revitalisasi ruang dengan alternatif kegiatan di malam hari investasi pada tata hijau sebagai peneduh

- Bangunan: perkantoran, bangunan fasilitas sosial

- Lahan: perkantoran, bangunan fasilitas sosial
- Sirkulasi: dua arah, bebas parkir

b) Tata Massa:

- KLB: $60 \%$

- KDB: $40 \%$

- Ketinggian: 2 lantai

- Sempadan: 12 meter dari as jalan

- Fasade: orientasi dan bentuk menyesuaikan ruang jalan

- Elemen: atap miring, joglo, kombinasi atap tradisional

c) Lansekap:

- Pagar: dinding tembok

- Vegetasi: Tanaman peneduh dan pengarah

9) Penataan Bangunan di sekitar Alun-Alun Selatan:

a) Guna Lahan:

- Strategi bangunan: penataan pedagang kaki-lima investasi tata hijau sebagai peneduh antisipasi terhadap keberadaan Kandang Gajah

- Bangunan: bebas bangunan, kecuali Sasana Hinggil dan Dalem Pra-bukusuman

- Lahan: Alun-alun sebagai ruang terbuka bersama dan lingkungan Sasana Hinggil

- Sirkulasi: satu arah, parkir satu sisi

b) Tata Massa:

- KLB: -

- KDB: -

- Ketinggian: -

- Sempadan: -

- Fasade: -

- Elemen: -

c) Lansekap:

- Pagar: dinding tembok

- Vegetasi: tanaman peneduh dan pengarah

Secara umum Peraturan Bangunan Khusus diharapkan mampu memberi arah bagi langkah perawatan bangunan cagar budaya berikut lingkungan di sekitarnya yang mempunyai nilai budaya yang penting. 
II. C. PENYELENGGaraAn

PEMBANGUnAN

Beberapa peluang yang memungkinkan untuk menjadi pertimbangan di dalam penyelenggaraan pembangunan pada Kawasan Cagar Budaya Kraton Yogyakarta, meliputi:

1) Menjadikan Kawasan Kraton Yogyakarta satu kesatuan pengembangan kawasan.

2) Perkembangan era baru pariwisata.

3) Dukungan lintas sektoral pemerintah.

4) Kebutuhan akan lingkungan yang berkualitas.

5) Lingkungan bersejarah semakin diperhatikan dan diperlukan.

Dengan demikian diharapkan kegiatan rancang bangun sejak studi kelayakan, perancangan, rekayasakonstruksi, operasi-pemeliharaan, penataan lingkungan hidup-binaan, dan kemungkinan pemusnahan setiap bangun bangunan yang ada di Kawasan Cagar Budaya Kraton Yogyakarta dalam bentuk produk arsitektur, struktur, dan utilitas, pelaku pembangunan, proses-proses yang harus dilalui, dan perijinan yang harus dimiliki, mengacu pada kelima pertimbangan tersebut. Selain persyaratan dan ketentuan umum yang diberlakukan dalam setiap kegiatan pembangunan sebagaimana disebutkan dalam Perda Bangunan 4/88, untuk Kawasan Cagar Budaya Kraton Yogyakarta harus pula memenuhi beberapa persyaratan khusus. Hal ini dapat dikemukakan sebagai berikut:

1) Persyaratan Perancangan Bangunan: Untuk menjamin dihasilkannya produk perancangan bangunan yang memenuhi persyaratan dan ketentuan, logikanya produk tersebut harus digarap oleh Arsitek dan insinyur yang secara formal kualifikasinya dapat dipantau dari kepemilikan SIBP atau keanggotaan asosiasi profesi..

2) Persyaratan Pelaksanaan Bangunan

Tahap perancangan di dalam pelaksanaan pembangunan projek bangunan harus dilaksanakan oleh pelaksana yang memenuhi syarat. Untuk itu persyaratan dan ketentuan formal sebagaimana umumnya juga berlaku di Kawasan Cagar Budaya Kraton Yogyakarta. Terlebih bagi pekerjaan yang diborongkan. Namun demikian terdapat juga banyak pembangunan skala kecil yang dilaksanakan oleh perorangan. Untuk itu, pembinaan dari aparat lapangan sangat menentukan tertib pembanguan di kawasan ini.

3) Persyaratan

Pemanfaatan/Penggunaan Bangunan Dalam tahap pasca pembangunan, pada dasarnya tidak diperlukan persyaratan khusus bagi pemanfaatan atau penggunaan bangunan. Ketentuan yang berlaku secara umum, berlaku pula bagi Kawasan Cagar Budaya Kraton Yogyakarta. Persyaratan khusus baru akan diperlukan bila bangunan akan dimanfaatkan bukan seperti maksud awal bangunan tersebut didirikan.

4) Persyaratan Penghapusan Bangunan Ada kalanya bangunan atau bagiannya tidak lagi diperlukan, contohnya sebagai konsekuensi dari perubahan fungsi, karena akan ada perubahan bangunan, karena bangunan sudah runtuh dan membahayakan, dan sebagainya. Untuk itu diperlukan Ijin Penghapusan Bangunan (IHB) yang diajukan kepada Dinas Tata Kota. Sebagai perimbangannya, Dinas Tata Kota memberikan petunjuk seperlunya.

d. Persyaratan Keselamatan dan Kenyamanan Bangunan

Pengembangan dan penataan kawasan wisata Kraton Yogyakarta 
merupakan upaya terpadu untuk mewujudkan suatu citra kawasan yang diharapkan dapat tertata dengan baik berikut segala kompleksitasnya. Perubahan guna lahan di daerah tertentu, perlu dicermati kaitannya dengan bahaya runtuh dan kelongsoran. Agar supaya tidak terjadi dampak negatif, maka perlu adanya suatu kriteria sebagai berikut :

1)Bangunan yang berada di pinggir jalan raya dibatasi ketinggiannya, maksimum sesuai dengan Perda yang berlaku (maksimum 7 meter untuk bangunan di dalam beteng)

2)Bangunan dengan ketinggian tembok lebih dari 5 meter, perlu adanya perkuatan kolom dan fondasi bentuk telapak.

3)Jarak antar bangunan sekuarangkurangnya 1 meter, untuk memberi ruang agar sirkulasi udara tetap lancar.

4)Pemukiman di dalam kawasan diwajibkan setiap rumah untuk menanam tanaman keras yang produktif yang berfungsi untuk menyerap polusi udara

5)Bagi pemukiman di pinggir jalan raya, untuk mengurangi polusi suara dapat diatasi dengan memberi media antara sumber bunyi penerima berupa halaman rumput atau dengan barrier.

6)Untuk kawasan pemukiman di daerah sekitar Pulau Cemeti Tamansari (sebelah selatan pasar Ngasem), perlu larangan perubahan pola guna lahan yang masih kosong. Bangunan bersejarah yang saat ini masih berdiri, perlu diberi pagar pembatas serta dilakukan perawatan berkala. Selanjutnya, persyaratan umum keselamatan dan keamanan serta kenyamanan bangunan adalah sebagai berikut :

1) Persyaratan Keselamatan
Berdasarkan kriteria tersebut di atas, maka perlakuan bangunan rumah tinggal perlu adanya aturan keselamatan sebagai berikut:

a) Daya Dukung Tanah

Bangunan 1 lantai diletakkan di atas tanah dasar yang datar dengan daya dukung sesuai beban konstruksi yang dipikul. Tegangan tanah yang terjadi harus lebih kecil dari daya dukung tanah yang ada. Untuk bangunan 2 lantai, daya dukung didasarkan hasil penyelidikan mekanika tanah. Pembuatan sumur bor tidak dianjurkan untuk kepentingan umum dan pribadi.

b) Kekuatan Konstruksi

Kekuatan konstruksi yang ditinjau meliputi:

\section{Fondasi :}

Untuk struktur fondasi sangat terkait dengan daya dukung tanah, jenis dan kedalaman dasar fondasi dan besarnya beban yang didukung. Pada prinsipnya tegangan yang terjadi harus lebih kecil dari tegangan ijin tanah $(\square=\mathrm{P} / \mathrm{A}<$ $\square$ ijin).

Tembok:

Tembok yang pada dasarnya merupakan bangunan pengisi, dapat membahayakan bila tidak diberi penguat (kolom maupun balok). Penguat diberikan untuk setiap $12 \mathrm{~m}^{2}$ luasan tembok. Tembok diletakkan di atas struktur yang kuat (sloof).

Kolom dan Balok :

Struktur kolom dan balok harus mampu menahan gaya vertikal dan horizontal. Jumlah besi tulangan yang dibutuhkan didasarkan pada jumlah luasan penampang besi dibandingkan dengan luasan penampang beton (jumlah luas penampang 
tulangan antara $1-3 \%$ luas penampang beton).

c) Bahan Bangunan Konstruksi

Bahan bangunan yang digunakan meliputi bahan kayu, baja dan beton.

d) Bangunan Konstruksi lain Bangunan yang dimaksudkan adalah bangunan atap.

2) Kenyamanan Bangunan \& Kesehatan Lingkungan

Kenyamanan bangunan sangat dipengaruhi oleh penyediaan jaringan utilitas dan kondisi lingkungan. Jaringan utilitas yang mendukung tingkat kenyamanan bagi penghuninya adalah penyediaan air bersih, saluran drainase air hujan, pembuangan limbah cair (air kotor), tempat pembuangan sampah, fasilitas listrik, telekomunikasi dan ketersediaan jaringan bahaya kebakaran.

\section{e. Persyaratan Perijinan Bangu-} nan.

Beberapa pertimbangan yang pada saatnya diharapkan menjadi bagian dari rekomendasi terhadap persyaratan untuk mengajukan ijin bangun-bangunan yang berlaku secara khusus di Kawasan Cagar Budaya Kraton Yogyakarta, secara umum meliputi : persyaratan administratif, pertimbangan dari sudut arsitektur, pertimbangan dari sudut struktur-konstruksi, pertimbangan terhadap lingkungan, dan beberapa persyaratan yang perlu dipenuhi berkaitan dengan pelaksanaan, keselamatan kerja dan pemeliharaan.

1)Persyaratan Administratif, berhubungan dengan proses dalam tata laksana pengajuan ijin bangunan (berisi berbagai kelengkapan tentang: permohonan, perintah, jangka waktu, dan kewenangan dalam pengajuan maupun pemberian ijin bangunan), klasifikasi fungsi dan pemanfaatan bangunbangunan, proses perijinan, langkah-langkah pengawasan, dan sistem pembiayaan (dispensasi dan besarnya biaya untuk mengajukan ijin bangunan)

2)Pertimbangan Arsitektur, berisi berbagai pertimbangan tentang : berbagai rencana kota dan rencana-rencana khusus yang telah diberlakukan, syarat-syarat tentang lingkungan di sekitar bangunan, dan berbagai persyaratan bangunan

3)Pertimbangan Struktur dan Konstruksi, berisi berbagai pertimbangan tentang : syarat dan perhitungan konstruksi, penyelidikan terhadap kondisi tanah, jenis dan syarat bahan bangunan yang digunakan, pertimbangan struktur dan konstruksi untuk bagian-bagian bangunan, meliputi: pondasi, lantai, dinding (termasuk sekatsekat/partisi), kolom, langitlangit, atap dan penutupnya, pertimbangan konstruksi utama yang digunakan meliputi konstruksi-konstruksi: beton bertulang, baja, kayu, dan bambu, system drainase, dan system instalasi.

4)Pertimbangan Pelaksanaan, Keselamatan Kerja, dan Pemeliharaan: berisi berbagai pertimbangan tentang: ketinggian bangunan, perombakan bangunan, penambahan bangunan, pembetulan bangunan, pagar sementara, perancah, keselamatan kerja, dan pemeliharaan. Pengajuan terhadap ijin bangunan di dalam Kawasan Cagar Budaya Kraton Yogyakarta, dapat berupa : 
pemberian ijin terhadap pengajuan atas bangun-bangunan tertentu dengan pertimbangan telah dipenuhinya berbagai persyaratan yang telah ditentukan, penolakan terhadap ijin bangunan karena tidak dipenuhinya salah satu syarat dalam pengajuan ijin bangunan, tidak diperlukannya ijin untuk jenis bangun-bangunan tertentu, pencabutan ijin bangunan, pembaharuan ijin bangunbangunan, dan berbagai kemungkinan tentang keberatan terhadap keputusan yang telah diberikan oleh instansi yang berwenang dalam bentuk banding kepada Kepala Daerah maupun Dewan Perwakilan Rakyat.

f. PENGAWASAN MENDIRIKAN BANGUNAN

Kegiatan pengawasan dalam mendirikan bangunan selayaknya diperuntukkan bagi bangunan baru maupun bangunan lama yang mengalami perbaikan. Kegiatan pengawasan ini diharapkan dapat berjalan secara menerus dan berkesinambungan. Substansi pengawasan ini diharapkan dapat menyentuh pada beberapa kegiatan yang merupakan proses dari pembangunan yang terlanjutkan. Pembangunan terlanjutkan tersusun atas tahapan-tahapan pembangunan: studi kelayakan (feasibility study), perancangan (design-engineering), penga-daan sumber daya (procurement), rekayasa-konstruksi (costruction), operasi dan pemeliharaan (operation and maintenance), bionomik-lingkungan (bionomic), pemusnahan (demolishion).. Beberapa bangunan yang ada di Kawasan Cagar Budaya Kraton Yogyakarta dapat muncul sebagai konflik karena tidak dipenuhi pertimbangan tersebut. Berbagai kegagalan dapat terjadi pada masing-masing tahap, dan menjadi kewajiban bagi institusi yang terkait di dalam pengawasan pembangunan, untuk senantiasa memantau tumbuh kembang pembangunan baik bangunan baru, maupun pemeliharaan dalam bentuk pemugaran. Pengawasan yang dilakukan pada tiap tahapan pembangunan, diharapkan dapat memberi arah pada tujuan ditetapkankannya perturan bangunan khususnya di Kawasan Cagar Budaya Kraton Yogyakarta meliputi: pemanfaatan tanah, perwujudan bangunan, sistem pergerakan di dalam dan diluar tapak, dan tata ruang luar dari masing-masing bangunan. Pengawasan pembangunan di dalam Kawasan Cagar Budaya Kraton Yogyakarta mekanismenya dilaksanakan oleh berbagai pihak. Dapat disebutkan adalah aparat Pemerintah Daerah yang dibentuk untuk menangani pelaksanaan penataan bangunan di Kawasan Cagar Budaya Kraton Yogyakarta, maupun pengawasan perorangan dan formal serta masyarakat.

g. PembinaAn

Pembinaan merupakan pengawasan pembangunan pada tataran ide. Pembinaan dijalankan dengan beberapa cara. Pada dasarnya pembinaan dilakukan dengan melakukan pemantauan yang terus menerus terhadap bangunan-bangunan yang sudah berdiri. Pertimbangan yang harus dilakukan dalam rangka pembinaan dalam rangka persiapan disusunnya peraturan bangunan khusus Kawasan Cagar Budaya Kraton Yogyakarta adalah:
1)Kemungkinan munculnya konflik baru sebagai akibat dari penataan. 
2)Peningkatan ekonomi masyarakat yang berakibat pada kebutuhan ruang baru.

3)Pengelolaan perubahan fungsi ruang.

4)penggunaan ruang dan lahan.

Pertimbangan tersebut, diharapkan menjadi wacana pengaturan yang dijadikan pedoman bagi setiap pelaku pembangunan, dan peran serta swasta maupun masyarakat secara aktif terhadap perancangan, rekayasa, operasional pemeliharaan, dan kemungkinan pemusnahan, dalam bentuk pembinaan terhadap bangun bangunan yang sudah ada, maupun yang akan berkembang kemudian.

h. Insentif dan Disinsentif

Sebagai bagian dari upaya menjaga beberapa aset cagar budaya yang pada masa sekarang maupun kemudian masih dimungkinkan untuk dipertahankan keberadaannya diharapkan dapat muncul bentuk insentif (keringanan) dan disinsentif (pemberatan) tertentu. Bentuk penanganan insentif-disinsentif ini diharapkan dapat menjadi pertimbangan terhadap upaya pelestarian berbagai cagar budaya, khususnya bangunan yang ada di Kawasan Cagar Budaya Kraton Yogyakarta. Pada sisi lain pemberlakuan insentif ini diharapkan mampu menahan berbagai gejala perkembangan bangunan yang bergeser dan tidak memenuhi berbagai harapan serta persyaratan tentang bangunan yang seyogyanya berada di Kawasan Cagar Budaya Kraton Yogyakarta. Insentif ini sendiri dapat berupa insentif langsung dan tidak langsung. Insentif langsung diberikan pada kegiatan pembangunannya, misalnya:

1) pembebasan dari segala biaya perijinan .
2) bantuan dana pelestarian yang dianggarkan melalui kantor purbakala;

3) bantuan teknis berupa tenaga preservasi dalam pelaksanaan bangunan;

4) bantuan keahlian bidang preservasi dalam perancangan bangunan.

Insentif tidak langsung diberikan kemudian setelah tahap pembangunan. Di antaranya dapat disebutkan adalah:

1)keringanan pajak bumi dan bangunan

2)pembebasan bagian bangunan yang dipreservasi dari pajak bangunan

Bentuk disinsentif dapat diberlakukan untuk berbagai jenis bangunan yang tidak memenuhi persyaratan bangunan yang diberlakukan khusus untuk Kawasan Cagar Budaya Kraton Yogyakarta. Pada sisi lain disinsentif juga dapat diberikan bagi beberapa pemilik bangun-bangunan yang memeliki nilai budaya, khususnya yang telah ditetapkan sebagai cagar budaya apabila sejalan dengan perkembangan waktu akan diubah, dirombak, ditambah namun tidak sesuai dengan kaidah bangunan cagar budaya, khususnya apabila bangunan tersebut akan dihapus atau dimusnahkan. Sebagaimana insentif di atas, disinsentif juga dapat diberikan secara langsung dan tidak langsung. Disinsentif langsung misalnya:

1) Pengenaan retribusi yang tinggi untuk menghapus bangunan yang bernilai budaya

2) Pemberlakuan syarat adanya kelengkapan kajian terhadap nilai budaya bangunan yang dipermasalahkan.

Disinsentif tidak langsung diberikan kepada kegiatan pembangunan yang sudah terlanjur 
merusak bangunan bernilai budaya. Misalnya:

1)Rekonstruksi bagian bangunan yang dimusnahkan;

2)Renovasi bagian bangunan yang dirusak;

3)Denda menurut ketentuan perundang-undangan yang berlaku (UU 5/92);

4)Sanksi hukuman badan menurut perundang-undangan yang berlaku (UU 5/92).

\section{Kesimpulan}

A. Dari keseluruhan proses penelitian dapat ditarik kesimpulan dan saran berupa rekomendasi, sebagai berikut:

B. a. Kualitas Fisik Kawasan

Rekomendasi yang diharapkan muncul dari kondisi fisik yang ada di Kawasan Kraton, meliputi: aspek: tata ruang, tata bangunan dan lingkungan, serta transportasi dan prasarana fisik. Dari aspek tata ruang, rekomendasi yang diberikan diharapkan mampu:

1) Mengembangkan dan menata kembali tata ruang Kawasan Kraton, sehingga didapatkan gambaran yang jelas kesatuan tata ruang antara Kawasan Inti, Kawasan Penunjang-I, Kawasan Penunjang-II, dan Kawasan Penunjang-III. Kemungkinan yang dapat direkomendasikan adalah dengan mengatur dan menyesuaikan kembali pola tata ruang Kawasan Inti dan Kawasan Penunjang sesuai dengan peruntukannya.

2) Memberi arahan penataan ruang kawasan sesuai dengan dominasi kegiatan yang disarankan untuk tiap kawasan, sehingga tidak terjadi kesenjangan arahan penatan kawasan yang satu dengan yang lain

3) Pengaturan pola tata ruang Kawasan Kraton dapat dilakukan dengan mengatur kembali pola dan struktur jaringan sirkulasi yang menghubungkan antara satu kegiatan dengan kegiatan yang lain, maupun antara satu kawasan dengan kawasan yang lain.

4) Memberi ciri khusus yang dapat mewakili keberadaan tiap kawasan melalui pelestarian elemen kawasan

5) Peningkatan kualitas kawasan, melalui peningkatan kualitas dan kapasitas prasarana dan sarana kawasan, perbaikan lingkungan permukiman dan lingkungan yang menimbulkan berbagai konflik.

6) Menata dan mengexpose kembali sisa artefak yang ada agar tidak musnah oleh perkembangan permukiman dan kegiatan masyarakat.

7) Mengupayakan penyelesaian tata ruang dan permasalahan tanah, khususnya yang berkaitan dengan upaya pengaturan bangunan di Kawasan Kraton melalui pendekatan yang terpadu

8) Penataan tanaman di lingkungan permukiman, sekitar artefak, yang berkaitan pada awalnya memberi nuansa lingkungan di Kawasan Kraton.

b. Tata Bangunan dan Lingkungan Upaya yang dilakukan sebagai rekomendasi, meliputi:

1) Upaya penyelematan berbagai artefak yang ada dan tersisa melalui langkah konservasi.

2) Penataan kembali berbagai fungsi dan kegiatan yang ada pada tiap kawasan sesuai dengan peruntukannya.

3) Upaya penetapan tolok ukur sebagai alat dalam melakukan pengawasan terhadap kepadatan bangunan, malalui: pengaturan jumlah bangunan permukiman, pengaturan luasan bangunan permukiman, strukturisasi pola permukiman, sejalan dengan fungsi 
peruntukan pada tiap kawasan, khususnya yang berada di dalam dan sekitar cagar budaya

4) Menata kembali keberadaan ruang terbuka sehingga memperjelas gambaran tentang keberadaan cagar budaya dan situs yang ada di Kawasan Kraton

5) Upaya penetapan tolok ukur sebagai alat dalam melakukan kontrol terhadap fungsi bangunan, melalui:

- Pembatasan perkembangan permukiman khususnya disekitar situs dan kawasan cagar budaya, perkembangan fungsi yang mampu menunjang keberadaan situs dan cagar budaya khususnya bagi pengembangan pariwisata

- Upaya penyusunan pedoman perancangan (design guidelines), sebagai acuan pembatasan ketinggian dan jumlah lantai bangunan, konstruksi bangunan, komposisi dan sintaksis bangunan, sesuai dengan misi yang harus diemban pada tiap kawasan, tanpa meninggalkan keberpihakan baik bagi keperluan pelestarian situs dan cagar budaya, sehingga tercipta arsitektur yang selaras pada tiap kawasan

- Penataan lansekap lingkungan melalui kajian terhadap pola dan elemen lansekap serta jenis tanaman, proses pembangunan dan pengelolaan, aspirasi dan kesadaran akan pentingnya pelestarian lingkungan situs dan cagar budaya sebagai suatu kebutuhan bersama

- Meninjau kembali beberapa kegiatan dan peruntukan atas bangunan yang telah bergeser dari kebijakan yang telah diberlakukan sebelumnya, agar keberadaannya selaras dengan perannya dalam mendukung situs dan cagar budaya.

\section{c. Sistem Transportasi}

Rekomendasi terhadap penataan sistem transportasi di Kawasan Kraton, meliputi:

1) Upaya mengatur struktur dan pola jaringan jalan.

2) Berupaya untuk menciptakan keterpaduan sistem parkir yang ada pada pusat kegiatan di tiap kawasan (khususnya Kraton, Tamansari-Ngasem, dan Benteng)

3) Penataan jaringan jalan yang berkaitan erat dengan sistem drainase kawasan, dan elemen estetika jalan (street furniture) .

d. Prasarana Fisik Rekomendasi penataan prasarana fisik yang ada di Kawasan Kraton, meliputi:

1) Penyusunan desain detail tentang prasarana utilitas.

2) Penyelenggaraan penyuluhan untuk keperluan: tata bangunan, lingkungan, dan prasarana fisik.

e. Sosial Ekonomi

Rekomendasi terhadap aspek sosial dan ekonomi di Kawasan Kraton, meliputi: upaya pengembangan sosial ekonomi yang tumbuh dari masyarakat Kawasan Kraton, dan pengembangan sosial ekonomi yang tumbuh dari sektor pariwisata, meliputi:

a) Pengembangan produk berorientasi ekspor

b) Pemberdayaan masyarakat melalui kemudahan akses terhadap informasi, modal, ketrampilan, teknologi, dan penguasaan pasar

c) Kemitraan antar pelaku ekonomi, baik dalam pengadaan modal, produksi, maupun pemasaran

d) Pembukaan jaringan pemasaran yang lebih luas di dalam dan di luar negeri

e) Peningkatan kualitas manajemen dan sumberdaya manusia 
f) Peningkatan peran serta aktif masyarakat

g) Mobilisasi sosial pada beberapa kegiatan yang mampu mengembangkan kebersamaan di dalam ikut menjaga kelestarian Kawasan Kraton

h) Pembinaan terhadap kelembagaan dan institusi yang telah diakui keberadaannya di tengah masyarakat Terciptanya kebersamaan dan kemitraan antara pemerintah daerah- Kratonswasta, dan masyarakat

Upaya pengembangan sosial dan ekonomi masyarakat melalui sektor pariwisata direkomendasikan dalam bentuk:

a) Pengembangan obyek dan daya tarik wisata, meliputi:

- Pengembangan obyek dan daya tarik wisata yang telah ada, yang berkaitan dengan situs dan cagar budaya yang ada dan akan dikonservasi kemudian

- Pengembangan obyek dan daya tarik wisata baru

- Pemberian penghargaan terhadap masyarakat yang peduli terhadap kelestarian cagar budaya

- Pelatihan teknik pelestarian dan konservasi

- Penataan manajemen pemeliharaan flora dan fauna di Kawasan Kraton

b)Pengembangan pasar wisata, melalui kegiatan promosi, dan sistem informasi

c) Pengembangan fasilitas dan infrastruktur

d)Peningkatan peran serta aktif kelembagaan dan sumberdaya manusia

\section{Daftar Pustaka}

Adrisijanti, Inajati. t.th. Arkeologi Perkotaan Mataram Islam. Penerbit Jendela, Yogyakarta.

Akihary, Huib. 1988. Architectuur \& Stedebouw in Indonesie. De Walburg Pers, Zutphen.
Anonim. 1980. Risalah Sejarah dan Budaya, Seri Peninggalan Sejarah.

Balai Penelitian Sejarah dan Budaya, Yogyakarta.

Budihardjo, Eko. 1986. Мепији Arsitektur Indonesia. Penerbit Alumni, Bandung.

Dakung, Sugiyarto. 1981/1982. Arsitektur Tradisional Daerah Istimewa Yogyakarta. Departemen Pendidikan dan Kebudayaan

DIY, Yogyakarta.

Departemen Pekerjaan Umum Kanwil Propinsi DIY, Proyek Perintis Perbaikan Lingkungan Perumahan Kota. 1986. Perencanaan Teknis Kawasan Kraton dan Alun-alun Lor dalam rangka Pengembangan Kawasan Malioboro Yogyakarta, Yogyakarta. Dinas Pendidikan dan Kebudayaan Propinsi DIY bekerjasama dengan Suaka Peninggalan Sejarah dan Purbakala Daerah Istimewa Yogyakarta. 1993/1994. Laporan Kegiatan Inventarisasi Asset Budaya

Kawasan Kraton Yogyakarta, Yogyakarta.

Dinas Pendidikan dan Kebudayaan Propinsi DI Yogyakarta. 1997/1998. Kajian Identitas Bentuk Bangunan Daerah Isitimewa Yogyakarta, Yogyakarta.

Dinas Pendidikan dan Kebudayaan Propinsi DI Yogyakarta. 1999. Peraturan Bangunan Khusus Kawasan Kraton Yogyakarta, Yogyakarta.

Dinas Pendidikan dan Kebudayaan Propinsi DI Yogyakarta. 1999. Laporan Analisis Dampak Lingkungan Kawasan Cagar Budaya Tamansari Yogyakarta, Yogyakarta.

Dinas Pendidikan dan Kebudayaan Propinsi DI Yogyakarta. 2000. Rencana Induk Pelestarian dan 